\title{
The carbon cycle in Mexico: past, present and future of $\mathbf{C}$ stocks and fluxes
}

G. Murray-Tortarolo ${ }^{1}$, P. Friedlingstein ${ }^{1}$, S. Sitch ${ }^{2}$, V. J. Jaramillo ${ }^{3}$, F. Murguía-Flores ${ }^{4}$, A. Anav ${ }^{1}$, Y. Liu ${ }^{5}$,

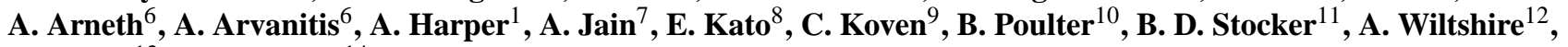
S. Zaehle ${ }^{13}$, and N. Zeng ${ }^{14}$

${ }^{1}$ College of Engineering, Mathematics and Physical Sciences, University of Exeter, Exeter, UK

${ }^{2}$ College of Life and Environmental Sciences, University of Exeter, Exeter, UK

${ }^{3}$ Instituto de Investigaciones en Ecosistemas y Sustentabilidad, Universidad Nacional Autónoma de México, Morelia, Mexico

${ }^{4}$ School of Geographical Sciences, University of Bristol, Bristol, UK

${ }^{5}$ Climate Change Research Centre, University of New South Wales, Sydney, Australia

${ }^{6}$ Institute of Meteorology and Climate Research, Karlsruhe Institute of Technology, Karlsruhe, Germany

${ }^{7}$ Department of Atmospheric Sciences, University of Illinois at Urbana-Champaign, Urbana, Illinois, USA

${ }^{8}$ Global Environment Program, Research \& Development Division, The Institute of Applied Energy, Tokyo, Japan

${ }^{9}$ Earth Sciences Division, Lawrence Berkeley National Laboratory, Berkeley, California, USA

${ }^{10}$ Institute on Ecosystems and the Department of Ecology, Montana State University, Bozeman, Montana, USA

${ }^{11}$ Department of Life Sciences, Imperial College, London, UK

${ }^{12}$ Met Office Hadley Centre, Exeter, UK

${ }^{13}$ Biogeochemical Intergration Department, Max Planck Institute for Biogeochemistry, Jena, Germany

${ }^{14}$ Department of Atmospheric and Oceanic Science and Earth System Science Interdisciplinary Center, University of Maryland, College Park, Maryland, USA

Correspondence to: G. Murray-Tortarolo (gnm202@exeter.ac.uk)

Received: 28 June 2015 - Published in Biogeosciences Discuss.: 10 August 2015

Revised: 7 December 2015 - Accepted: 17 December 2015 - Published: 15 January 2016

\begin{abstract}
We modeled the carbon (C) cycle in Mexico with a process-based approach. We used different available products (satellite data, field measurements, models and flux towers) to estimate $\mathrm{C}$ stocks and fluxes in the country at three different time frames: present (defined as the period 2000-2005), the past century (1901-2000) and the remainder of this century (2010-2100). Our estimate of the gross primary productivity (GPP) for the country was $2137 \pm 1023 \mathrm{TgC} \mathrm{yr}^{-1}$ and a total C stock of $34506 \pm 7483 \mathrm{TgC}$, with $20347 \pm 4622 \mathrm{TgC}$ in vegetation and $14159 \pm 3861$ in the soil.

Contrary to other current estimates for recent decades, our results showed that Mexico was a $\mathrm{C}$ sink over the period 1990-2009 (+31 $\left.\mathrm{TgC} \mathrm{yr}^{-1}\right)$ and that $\mathrm{C}$ accumulation over the last century amounted to $1210 \pm 1040 \mathrm{TgC}$. We attributed this sink to the $\mathrm{CO}_{2}$ fertilization effect on GPP, which led to an increase of $3408 \pm 1060 \mathrm{TgC}$, while both climate and
\end{abstract}

land use reduced the country C stocks by $-458 \pm 1001$ and $-1740 \pm 878 \mathrm{TgC}$, respectively. Under different future scenarios, the $\mathrm{C}$ sink will likely continue over the 21 st century, with decreasing $\mathrm{C}$ uptake as the climate forcing becomes more extreme. Our work provides valuable insights on relevant driving processes of the $\mathrm{C}$ cycle such as the role of drought in drylands (e.g., grasslands and shrublands) and the impact of climate change on the mean residence time of soil $\mathrm{C}$ in tropical ecosystems.

\section{Introduction}

The global carbon $(\mathrm{C})$ cycle has been altered by anthropogenic activity with the release of $\mathrm{CO}_{2}$ into the atmosphere through fossil fuel burning and land use and land cover changes since the industrial revolution (Keeling et al., 
1995). As a consequence $C$ stocks have increased in the atmosphere, land and oceans. About $50 \%$ of the annual anthropogenic emissions are sequestered in the marine and terrestrial ecosystems (Le Quéré et al., 2014). In the latter, the atmospheric $\mathrm{CO}_{2}$ increase has led to greater gross primary productivity (GPP), as a result of the fertilization effect on the plants' photosynthetic machinery, hence leading to higher C storage (Norby et al., 2005). However, GPP and the net biome productivity (NBP) display high interannual variability due to the effect of climate variability on vegetation processes (e.g., plant production and water use, growing season extension, fire, drought induced mortality; Sitch et al., 2015).

The interaction among climatic forcing, atmospheric $\mathrm{CO}_{2}$ and terrestrial $\mathrm{C}$ remains one of the main uncertainties in our understanding of the global $\mathrm{C}$ cycle and in our ability to model it, particularly concerning future projections. Different authors have documented contrasting qualitative and quantitative results regarding the future evolution of the land $\mathrm{C}$ cycle. These range from a strong future $\mathrm{C}$ sink due to a longer growing season in the Northern Hemisphere and the $\mathrm{CO}_{2}$ fertilization effect, to $\mathrm{C}$ sources from drought-induced tropical forest dieback and temperature-induced enhancements in mid-latitude soil respiration (Friedlingstein et al., 2006, 2013; Cox et al., 2000).

These differences in the future of land $\mathrm{C}$ arise from two sources: the strength of the carbon cycle feedbacks (driven by the sensitivity of land $\mathrm{C}$ to atmospheric $\mathrm{CO}_{2}$ increase and climate change) and the poor representation of smallerscale processes (e.g., disturbance) in the models (Ciais et al., 2013). Thus, regional studies are growing in importance to close the gap in our knowledge. These use finerresolution climate information and other data sources from the field (e.g., site-level carbon stocks), from satellites, and ecosystem-level information for particular regions. An example is the Regional Carbon Cycle Assessment and Processes (RECCAP) initiative, which has promoted studies on drivers of the land $\mathrm{C}$ cycle in different regions worldwide (e.g., Dolman et al., 2012; Gloor et al., 2012; King et al., 2015; Piao et al., 2012; Valentini et al., 2014), but further work is needed at finer scales (e.g., country level; Enting et al., 2012).

In this context, we centered our investigation on Mexico's $\mathrm{C}$ cycle. Until now, studies on the $\mathrm{C}$ stocks or fluxes at the country level have been estimated from changes in vegetation C due to land use change (Masera et al., 1997; Cairns et al., 2003) and more recently soil $\mathrm{C}$ has been incorporated in the calculations (de Jong et al., 2010). While these studies provide important insights on the processes driving the $\mathrm{C}$ cycle, e.g., land use/land cover change (LULCC), they place Mexico as a source of C (Pacala et al., 2007), which may be an incomplete conclusion derived from estimating $\mathrm{C}$ fluxes from biomass change only (Table 1). This approach results in important ecological processes not being taken into account, such as the effect of $\mathrm{CO}_{2}$ fertilization on GPP and the impacts of climate change or omitting soil $\mathrm{C}$ dynamics. In contrast, results from global models and atmospheric $\mathrm{CO}_{2}$ inversions place the country as a $\mathrm{C}$ sink (Hayes et al., 2012; King et al., 2012), but they lack a representation of the driving mechanisms of change. Hence, a study based on multiple sources of evidence, which takes into account the various driving processes of the land $\mathrm{C}$ in Mexico is needed; incidentally, to aid in policy formulation and to identify regions that may provide important ecosystem services like $\mathrm{C}$ sequestration.

In this study, we provide a country level perspective of the $\mathrm{C}$ cycle in Mexico and use different products and complementary approaches to estimate $\mathrm{C}$ stocks and fluxes over three different time frames: the present (2005-2009), the last century (1901-2000) and the remainder of this century (2010-2100). Mexico represents a unique opportunity to compare the different approaches for several reasons. The country includes four main mountain ranges, three of them along the Gulf of Mexico and the Pacific coasts and a volcanic belt, which cuts across the middle of the country from east to west (Challenger, 1998). It also comprises a large high central plateau, smaller-scale depressions, large alluvial plains and two topographically contrasting peninsulas. Thus, the topography in Mexico is among the most heterogeneous in the world. The funnel shape of the country (wide in the north and narrow to the south), along with the mountain ranges, the prevailing winds and the oscillations of the high-pressure subtropical belt contribute to a very high diversity of climates, with four of the five major climate types described by Koeppen represented in the country (Challenger, 1998; Espinosa et al., 2008). With few exceptions, most of the country shows a summer precipitation pattern. Climate types vary from very dry in the north to sub-humid and very humid in the south, which reflect a high variety of land cover types (Figs. 1 and S1 in the Supplement) and soils, as well. The high environmental heterogeneity also allows the multiple processes that drive the $\mathrm{C}$ cycle globally to be identified at an intermediate spatial scale (e.g., fire, drought, tropical deforestation), thus providing insights on the global drivers of the land $\mathrm{C}$.

We address the following research questions for the different time periods under consideration:

1. Present-day: what are the magnitudes of $\mathrm{C}$ stocks and fluxes at the country level? How do they vary geographically and by land cover type? How do the estimates with the different approaches compare?

2. Past: how have $\mathrm{C}$ stocks and fluxes changed over the last century? How do these relate to changes in atmospheric $\mathrm{CO}_{2}$, precipitation, temperature and land use?

3. Future: how are $\mathrm{C}$ stocks and fluxes projected to change over the 21 st century under different climate-change scenarios? 
Table 1. Different estimates for the land C-flux of the country. A negative sign indicates a source to the atmosphere and a positive sign a sink.

\begin{tabular}{lrlr}
\hline \multicolumn{3}{c}{ Land C flux estimates } \\
\hline Author(s) & Years & Method & $\begin{array}{r}\text { Estimate } \\
\text { (total) } \text { TgC yr }^{-1}\end{array}$ \\
\hline Masera et al. (1997) & $1985-1987$ & Changes in vegetation cover & -52.6 \\
Cairns et al. (2000) & $1977-1992$ & Changes in vegetation cover* & -18.6 \\
De Jong et al. (2010) & $1993-2002$ & Inventory based & -18.4 \\
Hayes et al. (2012) & $1993-2002$ & Inventory based & -18.4 \\
Hayes et al. (2012) & $2000-2006$ & Forward models & 29.0 \\
Hayes et al. (2012) & $2000-2006$ & Inverse models & 8.7 \\
This work & $1990-2009$ & DGVMs & 31.4 \\
& & Atmospheric Inversions & 21.4 \\
This work & & LULCC only & -19.5 \\
& $1901-2009$ & DGVMs & 12.1 \\
\hline
\end{tabular}

* This estimate accounts for only part of the south of Mexico.
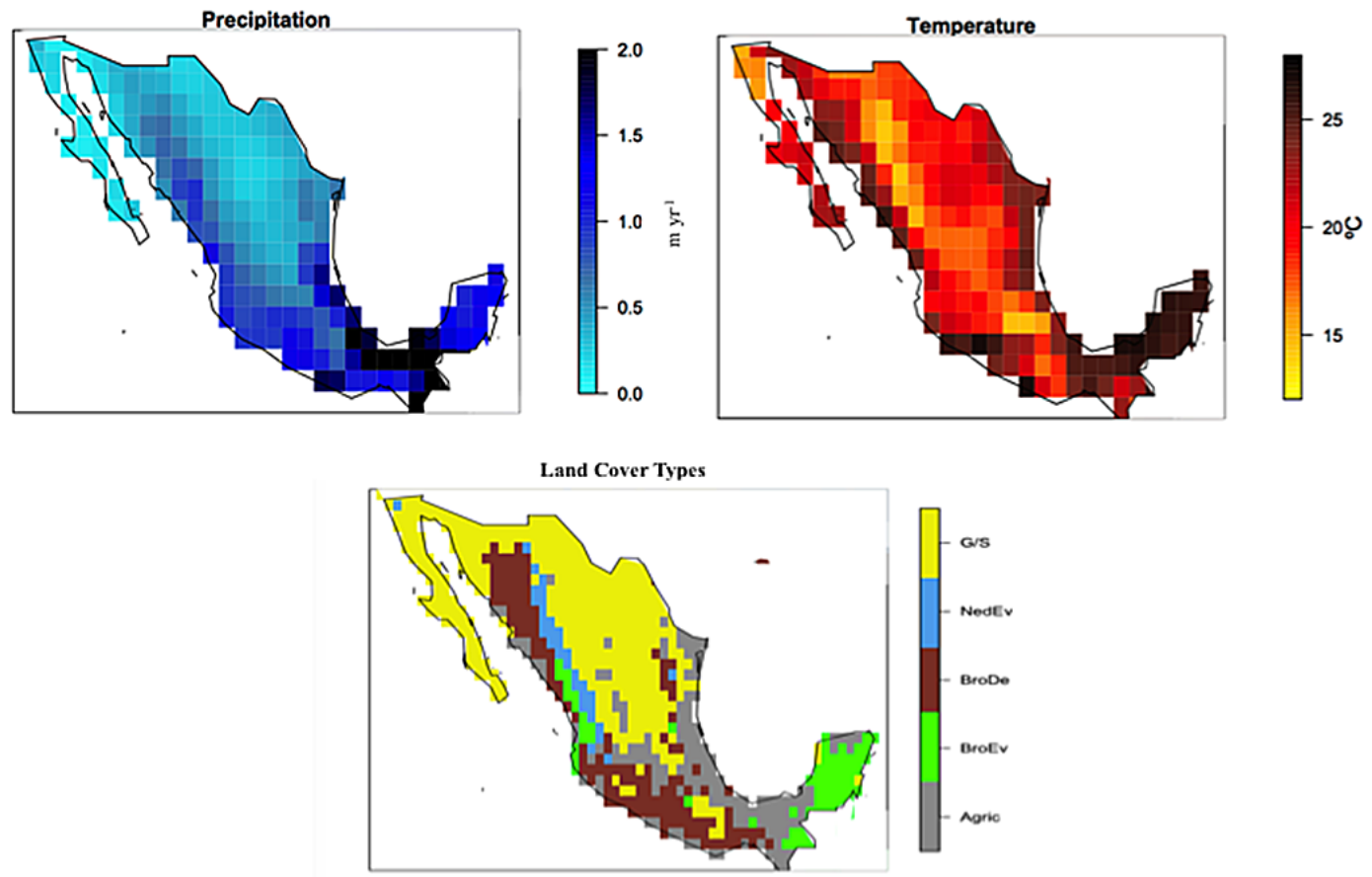

Figure 1. Observed precipitation $\left(\mathrm{m} \mathrm{yr}^{-1}\right)$, temperature $\left({ }^{\circ} \mathrm{C}\right)$, and land cover types for Mexico (mean of 2000-2005). Agric: croplands; BroEv: broadleaf evergreen forest; BroDe: broadleaf deciduous forest; NedEv: needleleaf evergreen forest; G/S: grassland/shrubland.

\section{Methods}

\subsection{Data sets}

Climate: We used observed temperature and precipitation data from CRU v3.1 (Harris et al., 2014), and we expressed the change over time as the total for the last century. These data, among other climatic drivers, were also used to force the dynamic global vegetation models (DGVMs; Fig. 1).
Present-day land cover: we used the observed vegetation data set by Ramankutty and Foley (1999). This was derived from satellite data and contains 18 different categories (Fig. 1). Ten categories were present in Mexico (Fig. S1). In order to simplify the analysis due to the spatial scale involved, we aggregated the vegetation into five broad categories: broadleaf evergreen forest, broadleaf deciduous forest, needleleaf evergreen forest, grassland/shrubland and croplands (Fig. 1d). 
Past LULCC: we used data for the agricultural fraction from Hyde et al. (2013), which was also used to force the DGVMs. LULCC emissions were obtained from the DGVMs. These data sets use a mixture of process-based and FAO country statistics to calculate the transformation of forest, agricultural areas, pastures and natural grasslands to other categories.

DGVMs: we used vegetation $\mathrm{C}$, soil $\mathrm{C}$, heterotrophic respiration (Rh), GPP and the NBP from an ensemble of 9 DGVMs (Fig. S2) from the TRENDY v2 project (Le Quéré et al., 2014; Sitch et al., 2015). All models were forced with the same input data and spin-up protocol. To attribute the relevant driver $\left(\mathrm{CO}_{2}\right.$ fertilization, climate or LULCC) of past change a set of factorial experiments was conducted over the period 1901-2012, where the effect of individual drivers and their combinations were analyzed. The runs were

- Simulation 1 (S1): rising $\mathrm{CO}_{2}$ through the century with constant climate and no LULCC; the $\mathrm{CO}_{2}$ effect only.

- Simulation $2(\mathrm{~S} 2)$ : rising $\mathrm{CO}_{2}$ through the century with real climate and no LULCC; the $\mathrm{CO}_{2}+$ climate effect.

- Simulation (S3): all drivers included (rising $\mathrm{CO}_{2}$, observed climate and land use change).

The attribution of the drivers was calculated as $\mathrm{S} 1: \mathrm{CO}_{2}$ effect only; S2 minus S1: climate effect only; S3 minus S2: LULCC effect only; and S3: the combined effect of all drivers and their interactions. A full description of the experiment can be found in Sitch et al. (2015).

Earth system models (ESMs): we used NBP, precipitation and temperature for four IPCC Representative Concentration Pathways or RCPs (2.6, 4.5, 6.0 and 8.5) based on an ensemble of 9 CMIP5 models common to all RCPs (Fig. S2) (Taylor et al., 2011). A full description of the models can be found in Anav et al. (2013).

Model tree ensemble (MTE): This is a data-driven model of GPP based on flux tower observations, the satellite fraction of the active photosynthetic active radiation (fAPAR) and climate fields. It uses a MTE, which is a machine learning system based on the data structure (Jung et al., 2011, 2009). We separated GPP from NEE (net ecosystem exchange) with the methodology from Reichstein et al. (2012). Although the MTE has been widely used, it is important to note that there are only a few flux towers in Mexico and only four of those are included in the algorithm. In recent years, more data have been incorporated to FLUXNET and results may vary when these are considered.

Satellite: to estimate aboveground biomass we used annual passive microwave satellite-based vegetation optical depth (VOD). VOD is an indicator of vegetation water content of aboveground biomass and can be approximated to mean biomass (Liu et al., 2011, 2013). We approximated the vegetation $\mathrm{C}$ from VOD using a linear coefficient for each cover type, derived from the best fit to the modeled aboveground biomass. To estimate GPP we used data derived from
MODIS v17 $\mathrm{f}$. The MODIS GPP algorithm is described in Running et al. (2004). A simple light use efficiency model (MOD17) is at the core of the GPP algorithm and it requires daily inputs of incoming photosynthetically active radiation (PAR) and climatic variables.

Field data: to estimate vegetation $\mathrm{C}$ we used the data from the REDD (reduce emissions from deforestation and forest degradation) -Mexico initiative, which contains extensive field measurements from the National Forestry Commission (Alianza MREDD+, 2013), for the year 2004 (Fig. S3). For soil C, we used the topsoil C concentrations $(0-20 \mathrm{~cm}$ depth) from 4000 sampling sites (Segura-Castruita et al., 2005) covering most of the country; soil sampling was conducted between 2000 and 2006. An alternative source for soil $\mathrm{C}$ was the harmonized soil database from FAO v1.2 (FAO/IIASA/ISRIC/ISSCAS/JRC, 2012). We multiplied C concentrations by the reference bulk density and the soil depth from the same database to estimate soil $\mathrm{C}$ stocks.

Atmospheric inversions: for the analysis on the land $\mathrm{C}$ flux for the present-day, we used the mean annual $\mathrm{CO}_{2}$ posterior flux from atmospheric $\mathrm{CO}_{2}$ inversion from 10 different products from Peylin et al. (2013) for the period 1990-2005. The uncertainty was calculated as the standard deviation across products. Due to the broad scale of the product $\left(5^{\circ} \times 5^{\circ}\right)$ we only provide the national average and not the gridded means.

All data sets were re-gridded to a common $1^{\circ} \times 1^{\circ}$ grid.

\subsection{Data limitations}

Although we tried to use data sets that represent the state-ofthe-art to our knowledge, the satellite retrievals, models (both DGVMs and ESMs), atmospheric inversions, flux tower data and field inventories contain different caveats that must be brought forward. We have summarized the advantages and limitations of each data set in Table 2. This implies that some results could potentially change in light of new and better constrained data in the future. In addition, we provide the link for all freely available data sets (Table S4 in the Supplement).

\subsection{Data analysis}

For the present-day analysis, we first computed the gridded mean GPP (satellite, MTE and DGVMs), soil C (field data, DGVMs and FAO) and aboveground vegetation $\mathrm{C}$ (field data, satellite and DGVMs) for the period 2000-2005. Then, we calculated those values for each land cover type and the total for the country for same time period, which was common to all data sets. We also computed the mean NBP from all DGVMs, but for an extended time period (1990-2009), as this flux is strongly affected by the interannual variability of the Earth system. Our best estimate for each $\mathrm{C}$ pool or flux was the mean across all products (i.e., the contribution of each product was equally weighted). The error was computed as the standard deviation for all years for all products pooled 
Table 2. Advantages and limitations of the different data sets used.

\begin{tabular}{|c|c|c|}
\hline Data set & Advantages & Limitations \\
\hline Satellite (biomass and GPP) & $\begin{array}{l}\text { High-resolution } \\
\text { Includes all driving mechanisms }\end{array}$ & $\begin{array}{l}\text { Not measured directly but derived from LAI, FPAR or } \\
\text { VOD. } \\
\text { Saturation over highly dense areas. } \\
\text { Need for interpolation when clouds are present. }\end{array}$ \\
\hline $\begin{array}{l}\text { Flux towers (MTE) GPP } \\
\text { and NBP }\end{array}$ & $\begin{array}{l}\text { In situ measurements } \\
\text { Includes all driving mechanisms }\end{array}$ & $\begin{array}{l}\text { Few sites in Mexico (4). But this is increasing rapidly. } \\
\text { Uses climatology to interpolate the data (added uncer- } \\
\text { tainty from climate databases). } \\
\text { Small interannual variability. }\end{array}$ \\
\hline $\begin{array}{l}\text { DGVMs (GPP, biomass, } \\
\text { soil C, NBP) }\end{array}$ & $\begin{array}{l}\text { Longer time period of all data sets (full } \\
\text { century) } \\
\text { Allow testing of individual driving factors } \\
\text { to attribute the change in NBP over time. }\end{array}$ & $\begin{array}{l}\text { Do not account for all ecosystem processes (e.g., some } \\
\text { models not include plant mortality, only few include a } \\
\text { representation of fire). } \\
\text { Broad uncertainty in the vegetation response to drought. }\end{array}$ \\
\hline $\begin{array}{l}\text { Biomass field data (national } \\
\text { inventory) }\end{array}$ & $\begin{array}{l}\text { In situ measurements } \\
\text { "land-truth" data }\end{array}$ & $\begin{array}{l}\text { Limited to one time slice. } \\
\text { Different sampling methodologies across country. } \\
\text { Point data that need to be interpolated. }\end{array}$ \\
\hline Soil field data (road data) & $\begin{array}{l}\text { In situ measurements } \\
\text { "land-truth" data }\end{array}$ & $\begin{array}{l}\text { Limited to one time slice. } \\
\text { Different sampling methodologies across country. } \\
\text { Only accounts for } \mathrm{C} \text { in the first } 20 \mathrm{~cm} \text { of the soil. } \\
\text { Point data that need to be interpolated. }\end{array}$ \\
\hline $\begin{array}{l}\text { Harmonized soil data set } \\
(\mathrm{FAO})\end{array}$ & $\begin{array}{l}\text { Standardized global product used in dif- } \\
\text { ferent fields. }\end{array}$ & $\begin{array}{l}\text { Broad approximation to soil } \mathrm{C} \text { based on soil type. } \\
\text { Only accounts for } \mathrm{C} \text { in the first } 20 \mathrm{~cm} \text { of the soil. }\end{array}$ \\
\hline Earth system models & $\begin{array}{l}\text { Only approach for future changes in land } \\
\text { C. } \\
\text { Commonly used in policy making } \\
\text { (IPCC). }\end{array}$ & $\begin{array}{l}\text { High uncertainty across ESMs, with little agreement of } \\
\text { the future change in NBP for most of the country. } \\
\text { Do not account for all driving factors (e.g., changes in } \\
\text { the nitrogen cycle). }\end{array}$ \\
\hline $\begin{array}{l}\text { Atmospheric } \mathrm{CO}_{2} \text { inver- } \\
\text { sions }\end{array}$ & $\begin{array}{l}\text { Includes all driving mechanisms } \\
\text { top-down approach }\end{array}$ & Broad-scale $\left(5^{\circ}\right)$, not suitable for gridded analysis. \\
\hline
\end{tabular}

together. We also computed a spatially weighted correlation across products.

For the analysis on past changes, we calculated cumulative NBP from the DGVMs ensemble for the period 1901-2000 (100 years) for the three different runs. We then attributed them to environmental drivers (change in NBP for the run $\mathrm{S} 1$ : $\mathrm{CO}_{2}, \mathrm{~S} 2$ minus $\mathrm{S} 1$ : climate and $\mathrm{S} 3$ minus S2: LULCC). We calculated the gridded linear change for each run and each driving factor (i.e., change in stored $\mathrm{C}$ by climate vs. precipitation and temperature trend). The mean residence time (MRT) of $\mathrm{C}$ in the soil was calculated by dividing the linear change of soil $\mathrm{C}$ by the change in soil heterotrophic respiration (Rh).

For the analysis on future scenarios, we calculated the change in cumulative NBP for each RCP from the ensemble of ESMs for the 21st century (2010-2100). We did this by grid, by land cover type, and for the whole country. For the gridded plots, we stippled the areas where at least $66 \%$ (6) of the models agreed on the sign of change in total stored C.

\section{Results}

\subsection{Present}

Total GPP for the country was $2137 \pm 1023 \mathrm{TgCyr}^{-1}$ for the period 2000-2005 (Table 3). In terms of the distribution by land cover type, the forest areas represented $56 \%$ of the total GPP and the croplands and grasslands/shrublands most of the rest $(44 \%)$. The highest GPP per unit area occurred in the broadleaf evergreen forests $\left(2.2 \pm 0.2 \mathrm{kgC} \mathrm{m}^{-2} \mathrm{yr}^{-1}\right)$ and the lowest in the grasslands and shrublands $\left(0.6 \pm 0.1 \mathrm{kgC} \mathrm{m}^{-2} \mathrm{yr}^{-1}\right.$; Table 3$)$. In terms of the country's geography, we found the highest GPP in the south and southeast with a steep decrease to the north; the lowest GPP occurred in north-central region (Fig. 2a). The three different products (i.e., satellite, flux towers (MTE) and DGVMs) displayed similar GPP distributions (Fig. 2b, c, d), with DGVMs estimating higher values over the mountainous ranges in the east and the west of the country and part of the central plateau. The spatial correlations between products were very high: satellite MTE $=0.97$, satellite DGVMs $=0.92$, and MTE DGVMs $=0.91$ (see also Fig. S4). 
Table 3. Mean GPP, total area and total GPP by land cover type for the period 2000-2005.

\begin{tabular}{lrrr}
\hline \multicolumn{4}{c}{ Gross primary productivity for Mexico (2000-2005) } \\
\hline Land cover type & Mean $\mathrm{kgC} \mathrm{m}^{-2} \mathrm{yr}^{-1}$ & Area $10^{9} \mathrm{~m}^{2}$ & Total $\mathrm{TgC} \mathrm{yr}^{-1}$ \\
\hline Broadleaf evergreen forest & $2.2 \pm 0.23$ & 257 & $553 \pm 264$ \\
Broadleaf deciduous forest & $1.2 \pm 0.16$ & 438 & $519 \pm 356$ \\
Needleleaf evergreen forest & $1.4 \pm 0.31$ & 92 & $134 \pm 34$ \\
Grassland/shrubland & $0.6 \pm 0.12$ & 747 & $420 \pm 260$ \\
Croplands & $1.2 \pm 0.09$ & 423 & $508 \pm 210$ \\
TOTAL & & 1957 & $2137 \pm 1023$ \\
\hline
\end{tabular}

(a)

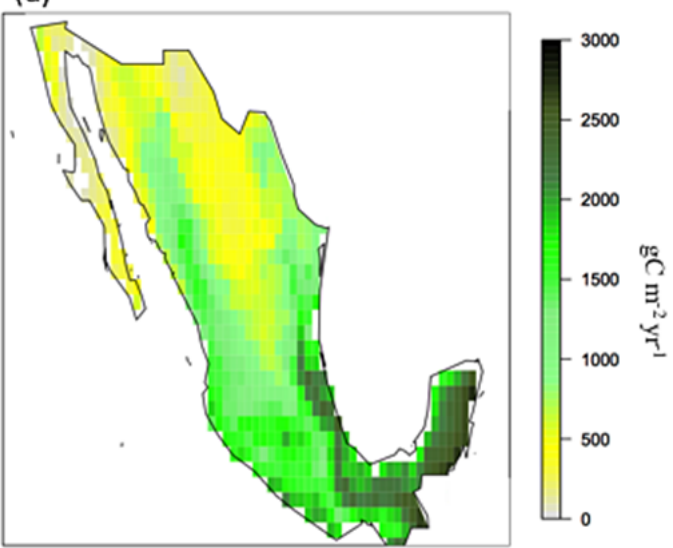

(b)

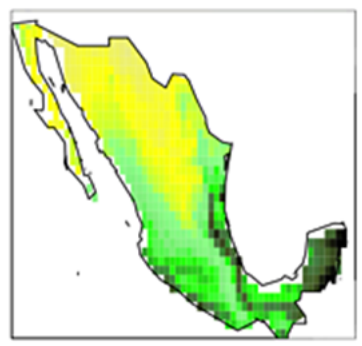

(c) MTE (fluxtower)

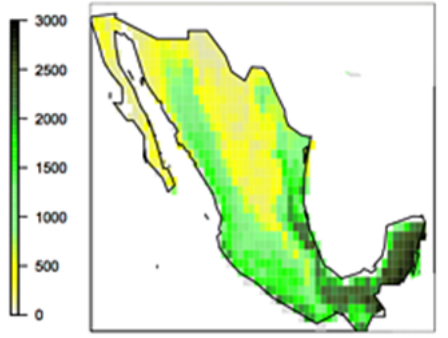

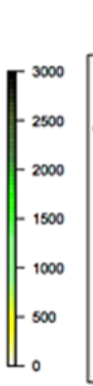

(d) DGVMs

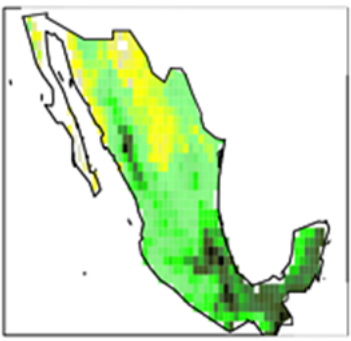

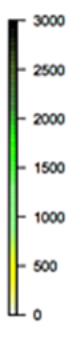

Figure 2. Mean GPP $\left(\mathrm{gC} \mathrm{m}^{-2} \mathrm{yr}^{-1}\right)$ for (a) ensemble of the three products, (b-d) individual products (Satellite, MTE and DGVMs). All maps correspond to the period 2000-2005.

Our estimate for the total $\mathrm{C}$ stock in Mexico was $34506 \pm 7843 \mathrm{TgC}$ (Table 4), of which $20,347 \pm 4622 \mathrm{TgC}$ $(59 \%)$ was stored in the vegetation and $14159 \pm 3861 \mathrm{TgC}$ $(41 \%)$ was stored in the soil (Table 4). Similar to GPP, the forested areas accounted for $60 \%$ of the total stored $\mathrm{C}$, with $40 \%$ in grasslands/shrublands and croplands. The broadleaf evergreen forest showed the highest $\mathrm{C}$ stock per unit area in the vegetation $\left(22.9 \mathrm{kgC} \mathrm{m}^{-2}\right)$ and soil $\left(12.1 \mathrm{kgC} \mathrm{m}^{-2}\right)$, whereas the grassland/shrubland the smallest $\left(6.0\right.$ and $4.7 \mathrm{kgC} \mathrm{m}^{-2}$, respectively; Table 4, Figs. 3 and S5).

Vegetation $\mathrm{C}$ estimates from the three products (DGVMs, satellite and field data) were in broad agreement at the country level and by land-cover type (Figs. 4 and S5). The largest differences among products were evident in the grassland/shrubland, with both DGVMs and satellite-based estimates $15-24 \%$ higher than those obtained from field measurements, which was evident in the geographical distribution of C stocks (Figs. 4a, b, c and S5). The spatial correlations between products were lower than for GPP: field DGVMs $=0.79$, field satellite $=0.84$, and DGVMs satellite $=0.74$.

The differences among products were greater for soil C. The field data estimates were on average $15 \%$ higher than with the other two products. In particular, the DGVMs and the FAO database appeared to underestimate soil $\mathrm{C}$ in the grasslands and shrublands in northern Mexico, with a value $27 \%$ lower than the field data (Figs. 4d, e, f and S5). 
Table 4. Mean $\left(\mathrm{kgC} \mathrm{m}^{-2}\right)$ and total $(\mathrm{TgC})$ carbon stored in the vegetation and soil in each land cover type for the period $2000-2005$.

\begin{tabular}{lrrrrrr}
\hline Total stored C & \multicolumn{2}{c}{ Vegetation C } & \multicolumn{2}{c}{ Soil C } & \multicolumn{2}{c}{ Total } \\
\hline Land cover type & $\begin{array}{r}\text { Mean } \\
\mathrm{kgC} \mathrm{m}^{-2}\end{array}$ & $\begin{array}{r}\text { Sum } \\
\mathrm{TgC}\end{array}$ & $\begin{array}{r}\text { Mean } \\
\mathrm{kgC} \mathrm{m}^{-2}\end{array}$ & $\begin{array}{r}\text { Sum } \\
\mathrm{TgC}\end{array}$ & $\begin{array}{r}\text { Mean } \\
\mathrm{kgC} \mathrm{m}^{-2}\end{array}$ & $\begin{array}{r}\text { Sum } \\
\mathrm{TgC}\end{array}$ \\
\hline Broadleaf evergreen forest & $22.9 \pm 0.9$ & $5884 \pm 1220$ & $12.1 \pm 0.4$ & $3100 \pm 1167$ & $35.0 \pm 1.3$ & $8984 \pm 2387$ \\
Broadleaf deciduous forest & $12.4 \pm 0.5$ & $5431 \pm 1319$ & $8.9 \pm 0.6$ & $3880 \pm 1235$ & $21.3 \pm 1.1$ & $9311 \pm 2554$ \\
Needleleaf evergreen forest & $15.1 \pm 0.9$ & $1385 \pm 575$ & $10.9 \pm 0.4$ & $1336 \pm 586$ & $26.0 \pm 1.3$ & $2721 \pm 1161$ \\
Grassland/shrubland & $6.0 \pm 0.7$ & $4482 \pm 1556$ & $4.7 \pm 0.7$ & $3535 \pm 1208$ & $10.7 \pm 1.4$ & $8017 \pm 2764$ \\
Cropland & $7.5 \pm 0.3$ & $3158 \pm 1190$ & $6.2 \pm 0.5$ & $2635 \pm 790$ & $13.7 \pm 018$ & $5793 \pm 1980$ \\
TOTAL & & $20347 \pm 4622$ & & $14159 \pm 3861$ & & $34506 \pm 7483$ \\
\hline
\end{tabular}

Total C Stored

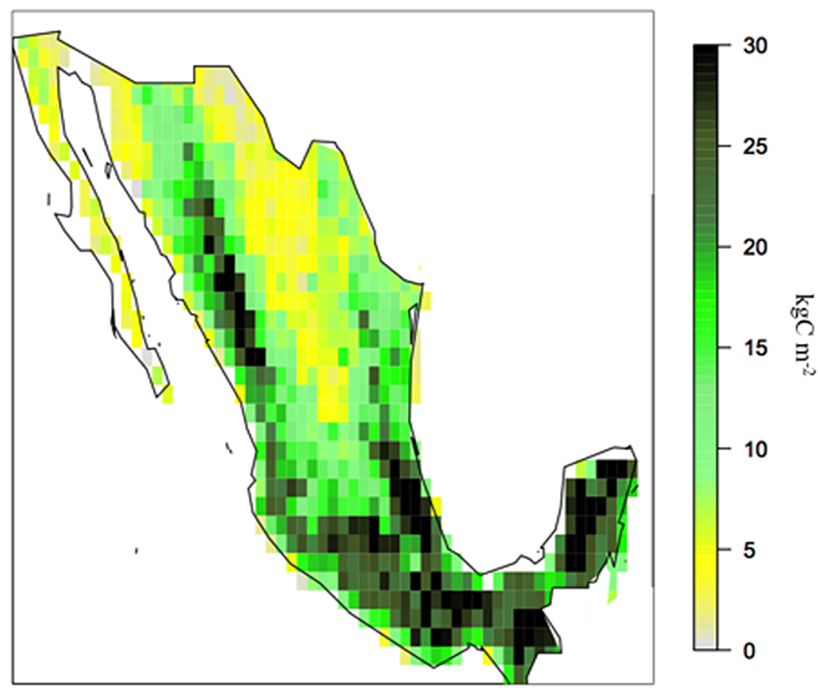

Figure 3. Total stored $\mathrm{C}$ in soil and vegetation $\left(\mathrm{kgC} \mathrm{m}^{-2}\right)$, ensemble from all products (6) for the period 2000-2005.

Nonetheless, there were similarities in the geographical patterns across products, which depicted generally higher soil C towards the south and lower towards the north, particularly in the central region. The spatial correlations between products were generally lower than for vegetation $\mathrm{C}$ stocks: field DGVMs $=0.68$, field $\mathrm{FAO}=0.69$ and DGVMs FAO $=0.92$.

Our results showed that Mexico was a sink of $\mathrm{C}$ over recent decades (1990-2009), gaining 31.4 $\pm 18.6 \mathrm{TgC} \mathrm{yr}^{-1}$ (Table 5). However, the sink was not equally distributed across land covers, with the broadleaf evergreen forest, the needleleaf evergreen forest and the grasslands gaining $\mathrm{C}$, but the broadleaf deciduous forest and the croplands losing $\mathrm{C}$. In terms of the geographical distribution of NBP, most of the country displayed positive values, except in areas of the northwest and the central east of the country, which lost C (Fig. 5). The atmospheric inversions also displayed a positive value for the country with a value of $21.4 \pm 12.7 \mathrm{TgC} \mathrm{yr}^{-1}$ (Table 1).
Table 5. Land C flux to the atmosphere (NBP) for the period 19902009 by land cover type. For all cases a positive value indicates a sink and a negative value a source.

\begin{tabular}{lrr}
\hline \multicolumn{3}{c}{ Land C Flux for Mexico (1990-2009) } \\
\hline Land cover type & $\begin{array}{l}\text { Mean \& total } \\
\mathrm{gC} \mathrm{m}^{-2} \mathrm{yr}^{-1}\end{array}$ & $\mathrm{TgC} \mathrm{yr}^{-1}$ \\
\hline Broadleaf evergreen forest & 100.8 & 20.6 \\
Broadleaf deciduous forest & -42.1 & -8.9 \\
Needleleaf evergreen forest & 22.2 & 1.5 \\
Grassland/shrubland & 55.2 & 21.3 \\
Croplands & -52.2 & -3.1 \\
TOTAL & & $31.4 \pm 18.6$ \\
\hline
\end{tabular}

\subsection{Past}

The model results with the DGVMs showed that Mexico has been a $\mathrm{C}$ sink over the last century, during which time there was an overall gain of $1210 \pm 1040 \mathrm{TgC}$. Geographically, NBP was not homogeneously distributed. The south and central regions of the country lost $\mathrm{C}$, while broad regions towards the north and the Yucatán Peninsula represented a C sink (Fig. 6). Three drivers of these regional trends could be identified at this scale with the processes included in the DGVMs: (a) the rise in atmospheric $\mathrm{CO}_{2}$, (b) long-term climate variability and change, and (c) land use and land cover change (LULCC)

a. The effect of elevated $\mathrm{CO}_{2}$ led to enhanced $\mathrm{C}$ storage across the whole of Mexico ( $3408 \pm 1060 \mathrm{TgC}$ ), with the highest $\mathrm{C}$ gain occurring over the forested regions (Fig. 7).

b. Climate impacts were highly contrasting across the country. Thus, when accounted nationwide, the positive and negative effects almost counteracted each other, although the negative effect dominated the flux with emissions of $-458 \pm 1001 \mathrm{TgC}$. Climate led to a decrease in $\mathrm{C}$ storage over most areas of the country, with the exception of the northeast and the Yucatán Peninsula (Fig. 8a). Over the last 100 years, both precipitation and 
(a)

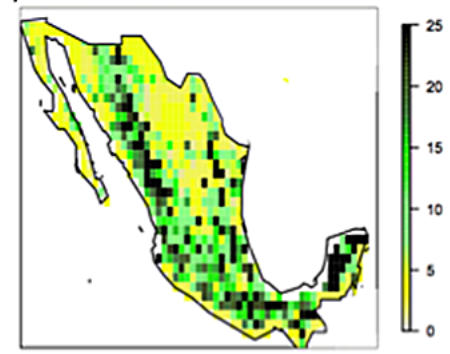

(d)
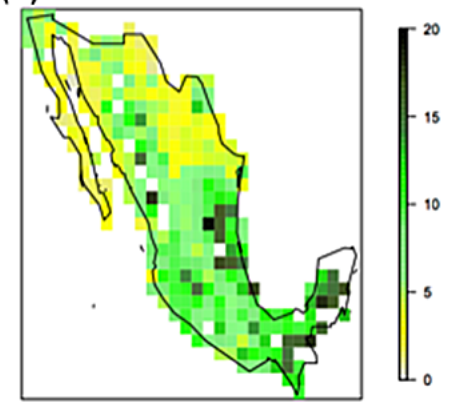

Vegetation Carbon $\left(\mathrm{kgC} \mathrm{m}^{-2}\right)$

(b)
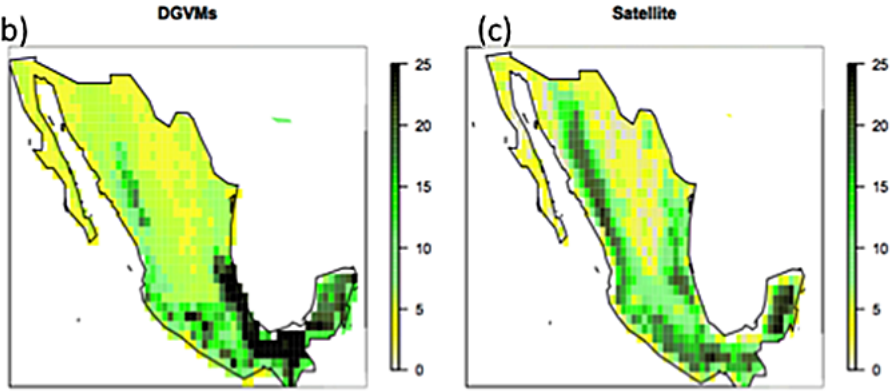

Soil Carbon $\left(\mathrm{kgC} \mathrm{m}^{-2}\right)$

(e)
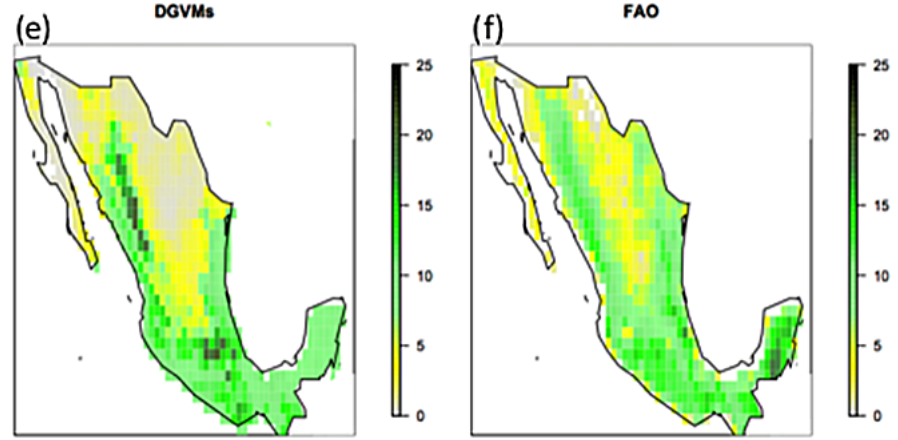

Figure 4. (Top) vegetation stored carbon for three products: field data, DGVMs and satellite $\left(\mathrm{kgC} \mathrm{m}^{-2}\right)$. (Bottom) soil stored carbon for three products: field data, DGVMs and FAO estimates based on multiple data sets $\left(\mathrm{kgC} \mathrm{m}^{-2}\right)$. Mean for the time period 2000-2005.

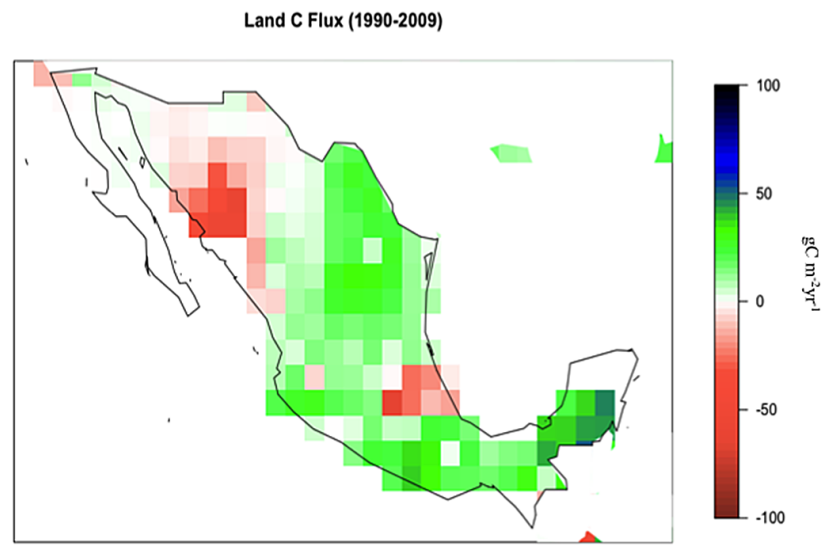

Figure 5. Land C flux (NBP) for the period 1990-2009 $\left(\mathrm{gC} \mathrm{m}^{-2} \mathrm{yr}^{-1}\right)$. A positive value indicates a $\mathrm{C}$ sink and vice versa.

temperature showed an increase in most of the country, except for decreases in precipitation especially in the Baja California Peninsula in the northwest (Fig. 8c). The loss of $\mathrm{C}$ over most of the country in spite of generally positive climate trends was driven by a faster increase of $\mathrm{Rh}$ than GPP, thus leading to a decrease in the mean residence time of soil C (Fig. S8). c. The negative effect of LULCL on total stored $\mathrm{C}$ $(-1740 \pm 878 \mathrm{TgC})$ occurred mostly over the south of the country and along the Gulf of Mexico and Pacific coasts (Fig. 9a). Carbon emissions from LULCC were apparently related to the distribution of changes in the agricultural fraction over the same time period (Fig. 9b). In addition, consistent with historical estimates and policies for LULCC the C emissions from LULCC were higher over the period 1950-1960, with a steep decline afterwards (Fig. S6).

Thus, when the three drivers were considered simultaneously, we found that the fertilization effect of $\mathrm{CO}_{2}$ on GPP during those 100 years was greater than the climate and LULCC negative effects, resulting in a positive net $\mathrm{C}$ storage at the scale of the country.

\subsection{Future}

In three out of four RCPs scenarios, the Earth system models predicted Mexico to remain a $\mathrm{C}$ sink up to 2100; only in the most extreme scenario (RCP8.5), would the country become a $\mathrm{C}$ source. The total amount of stored $\mathrm{C}$ decreased as the radiative forcing increased, from $3025 \mathrm{TgC}$ in $\mathrm{RCP} 2.6$, to $2150 \mathrm{TgC}$ in $\mathrm{RCP} 4.5$, to $1578 \mathrm{TgC}$ in RCP6.0 and $-762 \mathrm{TgC}$ in RCP8.5. 
Land C Flux (1901-2000)

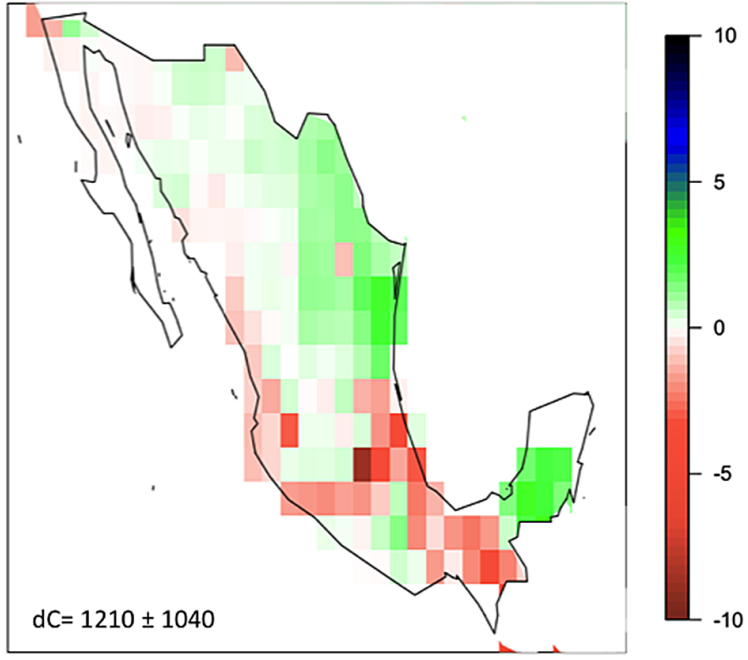

Figure 6. Total change in land $\mathrm{C}$ during 1901-2000 $\left(\mathrm{kgC} \mathrm{m}^{-2}\right)$. A positive sign indicates $\mathrm{C}$ gain. $\mathrm{dC}$ is total change in stored $\mathrm{C}(\mathrm{TgC})$.

Geographically, northern Mexico was generally a C source in all RCPs and at least two-thirds of the models agreed on this trend (Fig. 10). As the radiative force increased, most of the country turned into a $\mathrm{C}$ source and model agreement also increased. However, there was a significant uncertainty in the magnitude and even the sign of changes in other parts of the country, especially over the Yucatán Peninsula (Fig. 10).

Under all RCPs, precipitation decreased (Fig. S7) and temperature increased over the 21st century in the whole country (Fig. S6), with the larger changes occurring with increasing radiative forcing. Under these scenarios, very likely Mexico would face drier conditions, with the north of the country drying faster than the south.

\section{Discussion}

\subsection{Present}

The GPP (2137 $\left.\mathrm{TgC} \mathrm{yr}^{-1}\right)$ estimated in our study on Mexico corresponds to approximately $2 \%$ of the global values (Ciais et al., 2013), similar to the fraction of the land area the country represents. As far as we know, this is the first estimate of gross primary productivity at the country level combining different products. There are quite recent estimates of GPP at the site and regional levels determined from flux tower measurements of tropical dry forest in the northern range of its distribution (Verduzco et al., 2015; see Fig. S1) and from fPAR as a proxy of GPP for the Baja California Peninsula (Reimer et al., 2015). Tropical dry forest GPP was estimated at $831-1099 \mathrm{gC} \mathrm{m}^{2} \mathrm{yr}^{-1}$ (Verduzco et al., 2015), which is comparable to our mean estimate of $1200 \mathrm{gC} \mathrm{m}^{2} \mathrm{yr}^{-1}$ for broadleaf deciduous forest and to the
CO2-only C Flux (1901-2000)

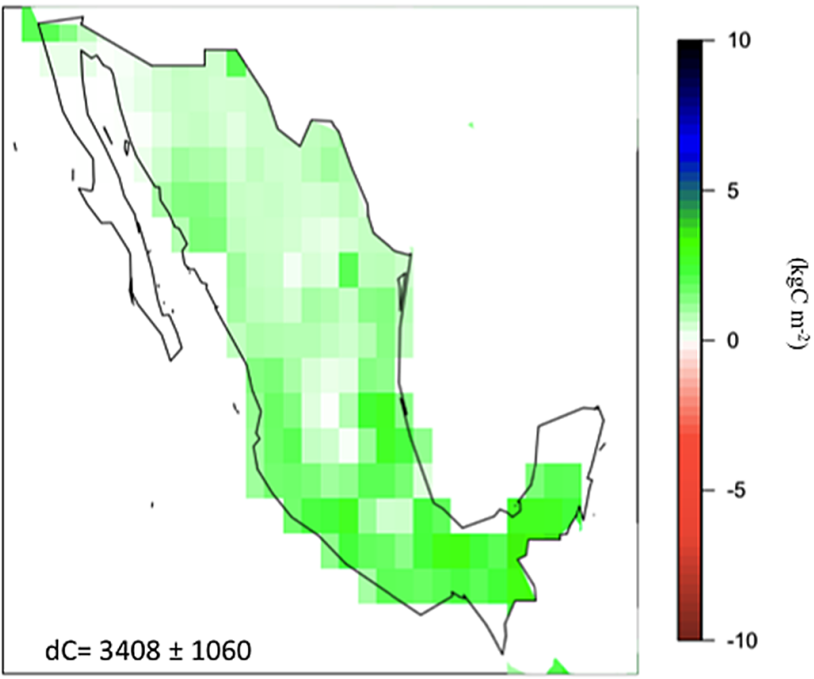

Figure 7. Change in total stored $\mathrm{C}$ by the effect of $\mathrm{CO}_{2}$ only over the period 1901-2000 $\left(\mathrm{kgC} \mathrm{m}^{-2}\right)$. A positive sign indicates $\mathrm{C}$ gain. $\mathrm{dC}$ is total change in stored $\mathrm{C}(\mathrm{TgC})$.

range of GPP values estimated for that NW region of the country. Also, GPP estimates for the Baja California Peninsula (700-960 $\mathrm{gC} \mathrm{m}^{2} \mathrm{yr}^{-1}$; Reimer et al., 2015) are comparable to the range of GPP values estimated in the peninsula from our study, especially to the satellite-derived estimates.

There are a few site estimates of net primary productivity (NPP) in Mexican ecosystems, since most studies use litterfall as a proxy for NPP (see for example the literature revision by Escobar et al., 2008). We can compare them by assuming NPP to be 0.5 of GPP (Farquhar and Sharkey, 1982). Among those, Martínez-Yrízar et al. (1996) estimated an aboveground NPP of $0.6-0.8 \mathrm{kgC} \mathrm{m}^{-2} \mathrm{yr}^{-1}$ in the tropical dry forest of Chamela, Mexico, similar to our findings of $0.6 \pm 0.2 \mathrm{kgC} \mathrm{m}^{-2} \mathrm{yr}^{-1}$ for broadleaf deciduous forest. García-Moya and Montanés-Castro (1992) estimated NPP in a semiarid grassland in central Mexico between 0.3 and $0.6 \mathrm{kgC} \mathrm{m}^{-2} \mathrm{yr}^{-1}$, similar to our finding of $0.3 \pm 0.2 \mathrm{kgC} \mathrm{m}^{-2} \mathrm{yr}^{-1}$ for grasslands/shrublands. Such overall agreement of GPP and NPP provides elements to constrain $\mathrm{C}$ fluxes, although more field measurements are needed to provide better comparisons at the country scale.

The total C stock (vegetation and soil) for the country of $34506 \pm 7483 \mathrm{TgC}$, estimated with different products (field data, DGVMS and satellite), differs from the $24000 \mathrm{TgC}$ estimated by Masera et al. (2001) with a $\mathrm{C}$ accounting model. More recent and comprehensive estimates put the total $\mathrm{C}$ stock for Mexico at around $33000 \mathrm{TgC}$ (Pacala et al., 2007), which is similar to our value. Interestingly, the baseline estimate of $19000 \mathrm{TgC}$ for the total $\mathrm{C}$ stock in forests by Masera et al. (2001) compares to our $20347 \mathrm{TgC}$ for forest vegetation. This means that the highest source of discrepancy across 
(a)

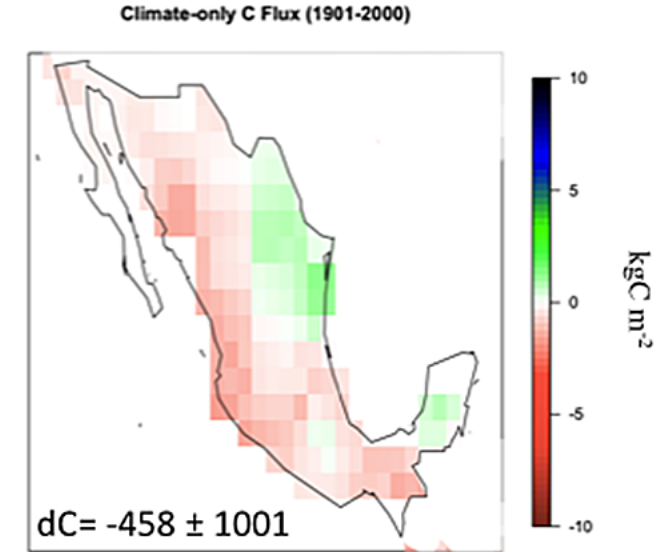

(b)

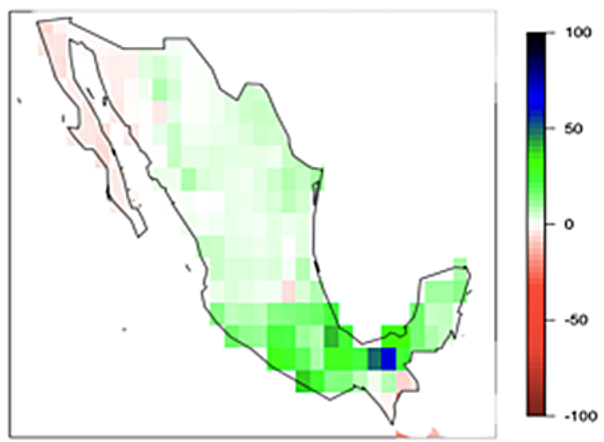

(c)

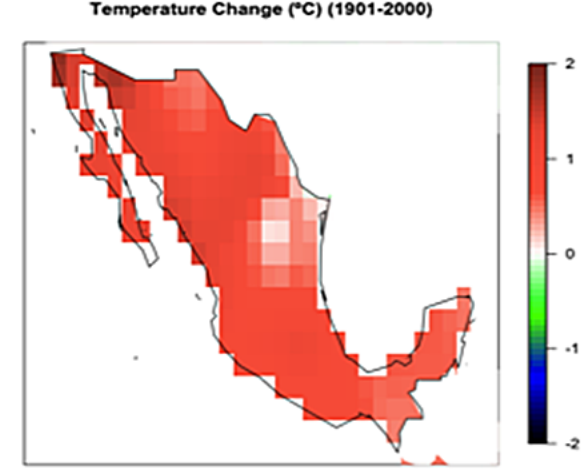

Figure 8. (Top) change in stored $\mathrm{C}$ by the effect of climate-only for the period $1901-2000\left(\mathrm{kgC} \mathrm{m}^{-2}\right)$. A positive sign indicates $\mathrm{C}$ gain. $\mathrm{dC}$ is total change in stored $\mathrm{C}(\mathrm{TgC})$. (Bottom) change in climate (precipitation and temperature) for the same time period.

(a)

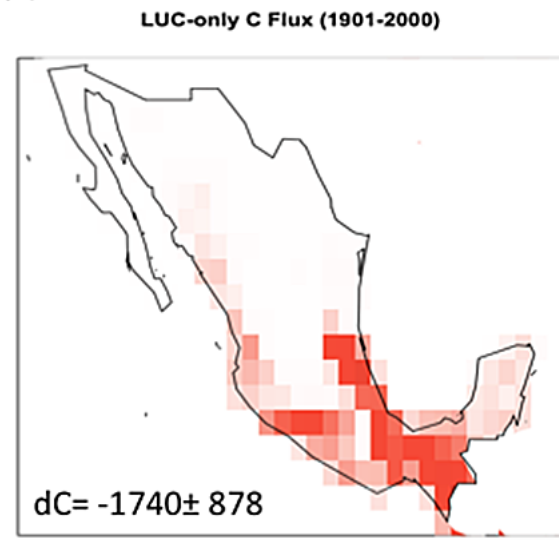

(b)

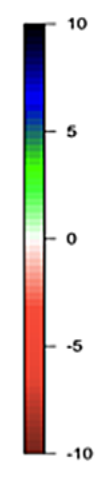

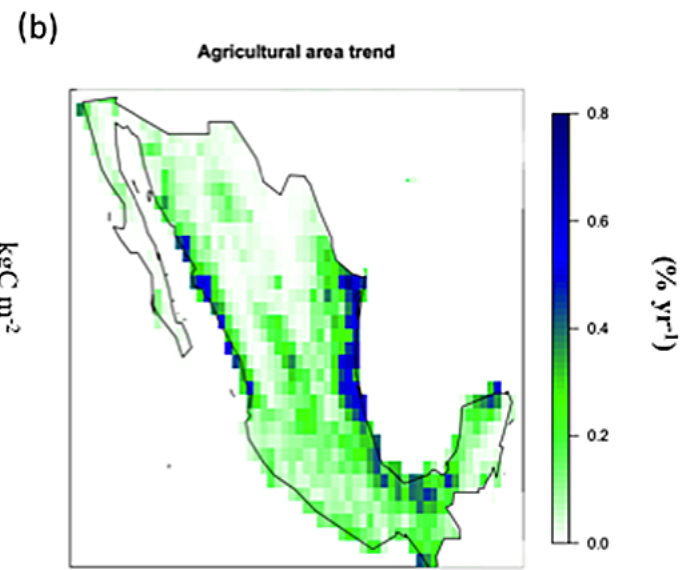

Figure 9. (a) Change in stored $\mathrm{C}$ by the effect of LULCC only for the period $1901-2000\left(\mathrm{kgC} \mathrm{m}^{-2}\right)$. A positive sign indicates $\mathrm{C}$ gain. $\mathrm{dC}$ is total change in stored $\mathrm{C}(\mathrm{TgC})$. (b) Agricultural area change for the same time period.

estimates concerns soil C, with our estimate of $14159 \mathrm{TgC}$ almost 3 times higher than Masera et al. (2001) of $5000 \mathrm{TgC}$.

Total aboveground biomass $\mathrm{C}$ for Mexico represents $\sim 4 \%$ of the global biomass stocks (Ciais et al., 2013). Our estimates for land cover types are difficult to compare to field-based studies because of the coarse scale of resolution used in our study, which provides large-scale averages and does not capture the heterogeneity of land cover at the local scale. Furthermore, difficulties arise when comparing with other modeling approaches because of differences in criteria to establish land cover classes and in the methods for calculation. Nevertheless, it is interesting that our mean esti- 


\section{Change in future land C (2010-2100)}

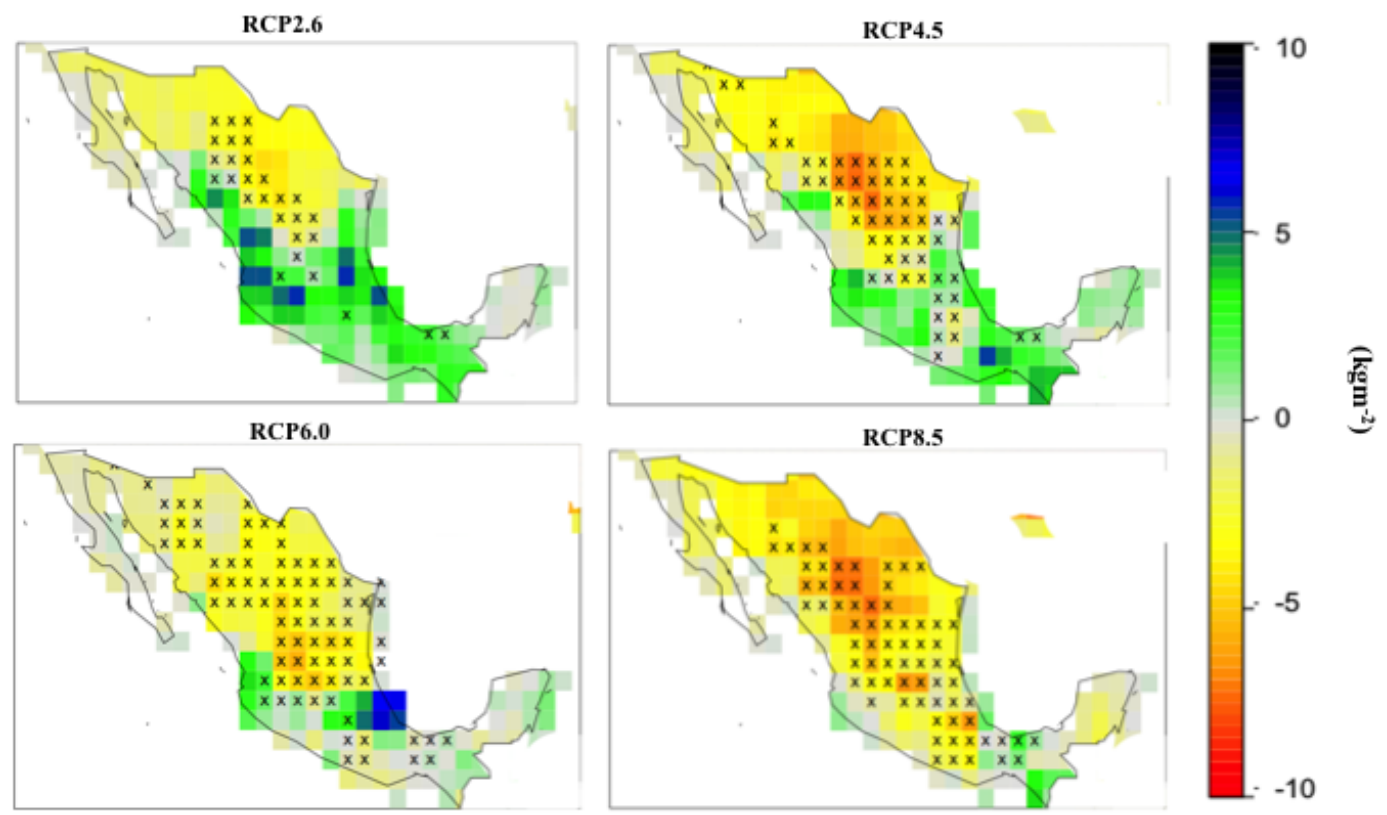

Figure 10. Gridded future change in total stored C for four RCPs for the period $2010-2100\left(\mathrm{kgC} \mathrm{m}^{-2}\right)$. The stippling represents areas where $>66 \%$ of the ESMs models agree on the sign of the flux.

mate of $22.9 \pm 0.9 \mathrm{kgC} \mathrm{m}^{-2}$ in the broadleaf evergreen forest is similar to the mean value of $20.5 \mathrm{kgC} \mathrm{m}^{-2}$ from Masera et al. (2001) for the same land cover, with a different modeling approach, and even to the $19.5 \mathrm{kgC} \mathrm{m}^{-2}$ reported for the Los Tuxtlas region from field measurements (Hughes et al., 1999). Also, our estimate for the needleleaf evergreen forest of $15.1 \pm 0.9 \mathrm{kgC} \mathrm{m}^{-2}$ compares to the mean temperate forest $\mathrm{C}$ stock of $12.6 \mathrm{kgCm}^{-2}$ of Masera et al. (2001). However, it is important to note that field measurements by Jasso (2014) showed a range from 2.1 to $20.8 \mathrm{kgC} \mathrm{m}^{-2}$ for pine and fir dominated forests depending on altitude, which indicates the high degree of variability for this land cover type. Important discrepancies were found over the grasslands/shrublands for which we estimated a mean vegetation $\mathrm{C}$ of $6.1 \pm 0.7 \mathrm{kgC} \mathrm{m}^{-2}$, while field studies (e.g., Búrquez et al., 2010; Navar et al., 2014) estimated $1.6-4.4 \mathrm{kgCm}^{-2}$ in the deserts over the north of the country. Broadleaf deciduous forest $\mathrm{C}$ is more difficult to compare to field-based estimates, since for the purposes of our study this land cover type combined oak and tropical dry forest.

Total soil C storage in the country is $\sim 0.6 \%$ of the global stock (Ciais et al., 2013 IPCC Chapter 6). This represents a smaller percentage than the other stocks and fluxes, because the FAO and field data used in this study included only the top $20 \mathrm{~cm}$ of soil; thus, the size of the soil C stock is underestimated. Batjes (1996) showed that, on average, topsoil $(20 \mathrm{~cm})$ represents one-third of the global soil C stock. A field study in the dry tropics of Mexico (Jaramillo et al., 2003) showed that $37-59 \%$ of the soil C stock was in the top
$20 \mathrm{~cm}$ of soil in land covers, which comprised dry and floodplain forest and pasture. In the tropical evergreen forest of Los Tuxtlas (Hughes et al., 1999), soil C in the top $30 \mathrm{~cm}$ of soil represented $46 \%$ of the soil C stock to a $1 \mathrm{~m}$ depth. Thus, the amount of $\mathrm{C}$ stored in soil at the country scale is likely to be at least twice as high as estimated here and further work is needed to better constrain this calculation. Nevertheless, our estimate for the $20 \mathrm{~cm}$ soil depth of $14.2 \mathrm{PgC}$ for the country compares to the $15.3 \mathrm{PgC}$ calculated by de Jong et al. (2010) in a study of the impact of LULCC on C stocks in Mexico. A more recent estimate based on extensive field measurements of soil organic $\mathrm{C}$ for the top $30 \mathrm{~cm}$ of soil (Cruz-Gaistardo and Paz-Pellat, 2014) provides $9.2 \mathrm{PgC}$ for the country. This implies that if soil inorganic $\mathrm{C}$ is accounted for, soil $\mathrm{C}$ stocks would be higher and likely similar to the estimates above. In fact, maximum soil C stocks occur in the Yucatán Peninsula, with soils rich in calcium carbonate, and in the southern edge of the eastern Sierra (Etchevers et al., 2014), which is consistent with the geographical distribution of soil $\mathrm{C}$ depicted in our study, especially as estimated from the field data set.

If we compare the estimates among products and consider the high correlations among them, it seems that the $\mathrm{C}$ stocks in the vegetation and the GPP fluxes are remarkably well constrained and compare favorably against field data and findings by other authors (Pacala et al., 2007). However, model development and improvement, particularly over non-forested areas, is needed, where the DGVM estimates showed the highest differences compared to field values. This is particularly important because in spite of the fact that dry- 
Table 6. Sensitivity of carbon to climate in four RCPs for the whole country. $\mathrm{dC}$ : change in total stored $\mathrm{C} ; \mathrm{d} T$ : change in mean land surface temperature; $\gamma$ : change in the land $\mathrm{C}$ flux relative to the change in temperature; $\gamma$ o land carbon sensitivity to climate in the past. A negative $\gamma-\gamma$ o implicates a detrimental effect of climate in the land $\mathrm{C}$ flux in the future compared to the present.

\begin{tabular}{lrrrr}
\hline Period/RCP & $\begin{array}{r}\mathrm{dC} \\
\mathrm{PgC}\end{array}$ & $\begin{array}{r}\mathrm{d} T \\
{ }^{\circ} \mathrm{K}\end{array}$ & $\begin{array}{r}\gamma \\
\mathrm{PgC} /{ }^{\circ} \mathrm{K}\end{array}$ & $\begin{array}{r}\gamma-\gamma \mathrm{O} \\
\mathrm{PgC} / \mathrm{vK}\end{array}$ \\
\hline $1901-2000$ & 1.2 & 0.88 & $1.36^{* *}$ & \\
$\mathrm{RCP} 2.6$ & 3.0 & 2.4 & 1.25 & -0.11 \\
$\mathrm{RCP} 4.5$ & 2.1 & 3.6 & 0.58 & -0.78 \\
$\mathrm{RCP} 6.0$ & 1.5 & 4.5 & 0.33 & -1.03 \\
$\mathrm{RCP} 8.5$ & -0.7 & 6.1 & -0.21 & -1.57 \\
\hline
\end{tabular}

lands only represent $25 \%$ of the GPP and C stocks, they account for nearly half the area of the country. This means that error propagation in this particular land cover may lead to changes in the estimations of the $\mathrm{C}$ cycle.

Our results showed that Mexico was a $\mathrm{C}$ sink over recent decades (1990-2009), gaining $31.4 \pm 18.6 \mathrm{TgC} \mathrm{yr}^{-1}$. This is similar to recent calculations by Hayes et al. (2012) using inverse $\left(+8.7 \mathrm{TgC} \mathrm{yr}^{-1}\right)$ and forward models $\left(29.0 \mathrm{TgC} \mathrm{yr}^{-1}\right)$ and to the result from atmospheric $\mathrm{CO}_{2}$ inversions $\left(21.4 \mathrm{TgC} \mathrm{yr}^{-1}\right)$. Also, recent flux tower estimates of net ecosystem production (NEP) in tropical dry forest at the site scale (Verduzco et al., 2015) have shown a predominant local C sink. Our results are in disagreement with inventory based calculations (Masera et al., 1997; Cairns et al., 2000; de Jong et al., 2010) that place Mexico as source of C (Table 1). The discrepancy may arise because the latter estimates are based on changes in vegetation stocks as fixed covers, which do not take into account other $\mathrm{C}$ fluxes and important ecosystem processes such as the effect of $\mathrm{CO}_{2}$ fertilization and the impact of climatic variables. In other words, those estimates are closer to the LULCC C-flux than to NBP (see Table 1). Based on our estimates and the recent literature, we argue that it is likely that Mexico is currently a sink and not a source of $\mathrm{C}$, if we disregard emissions from fossil fuels. The definition of Mexico as a $\mathrm{C}$ sink is consistent with the overall role of north America (USA and Canada; Hayes et al., 2012) and would place the north American C sink at approximately $377 \mathrm{TgC} \mathrm{yr}^{-1}$.

\subsection{Past}

Similar to the present-day, our results indicated that the terrestrial ecosystems in the country were a $\mathrm{C}$ sink over the last 100 years, gaining $1210 \pm 1040 \mathrm{TgC}$ in total. Such an increment was driven by the $\mathrm{CO}_{2}$ fertilization effect on vegetation $\left(3408 \pm 1060 \mathrm{TgCyr}^{-1}\right)$, which enhanced GPP and subsequently biomass and possibly soil $\mathrm{C}$ to different degrees. Both the climate $\left(-458 \pm 1001 \mathrm{TgCyr}^{-1}\right)$ and the land use $\left(-1740 \pm 878 \mathrm{TgCyr}^{-1}\right)$ drivers showed a generalized nega- tive effect on $\mathrm{C}$ storage. Our estimates are highly consistent with those derived from global models for Latin America, which show these land ecosystems as C sinks (Pan et al., 2011). However, during the period 1901-2000 the country's emissions from fossil fuels amounted to about $10600 \mathrm{TgC}$ (Le Quéré et al., 2014). This suggests that only $11 \%$ of the emissions from fossil fuels were actually captured back into the land and emphasizes the need for more efficient fossilfuel and LULCC policies.

The loss of C over NE Mexico is likely driven by climate. A long-term drought identified over this region and SE USA (Cayan et al., 2010) has led to a reduction in grassland productivity (Grover and Musick, 1990) and the subsequent loss of stored $\mathrm{C}$ due to increased dry season intensity and length (Murray-Tortarolo et al., 2015). However, the overall negative effect of climate on $\mathrm{C}$ storage in other regions is likely linked to its impact on soil C MRT (Fig. S8). The increase in temperature leads to a higher respiration rate and soil $\mathrm{C}$ loss. As the MRT decreases, it results in certain regions becoming a $\mathrm{C}$ source to the atmosphere. This source, nevertheless, is apparently overridden by the impact of higher precipitation on plant productivity in many regions of Mexico. In this sense, MRT is one of the main sources of uncertainty for the future of global soil C (Carvalhais et al., 2014; Friend et al., 2014) and a more comprehensive analysis over the country, based on observed data, is lacking.

Other regions that experienced $\mathrm{C}$ loss are linked to the impact of LULCC. LULCC accounted for a loss of $1740 \mathrm{TgC}$ over this period, with most of the emissions $(60 \%)$ occurring in forested regions and $32 \%$ in the broadleaf forests over the south. Interestingly, about one-third of the emissions (34\%) were accounted for in croplands. Country-level estimates by Masera et al. (1997) calculated the flux at $61 \mathrm{TgC} \mathrm{yr}^{-1}$ based on changes only in vegetation stocks for their baseline year in the 1980s. More comprehensive analyses including $\mathrm{C}$ emissions from the soil $\mathrm{C}$, estimated net emissions of 23.7 $\mathrm{TgC} \mathrm{yr}^{-1}$ from LULCC in forests of Mexico for the period 1993-2002 (de Jong et al., 2010; Hayes et al., 2012). Despite the different methodologies, all approaches establish that the highest LULCC emissions fluxes have occurred mostly over southern Mexico.

When the effects of all drivers were considered, the models showed that changes in climatic variables had a smaller impact on stored C than LULCC during the period 19012009. This was due to the fact that the impacts of LULCC were consistently negative on all land cover types, whereas climatic variables showed a heterogeneous effect (i.e., positive and negative) on the land cover types, which are differentially distributed over the country. Notably, climate trends have promoted $\mathrm{C}$ capture in broadleaf evergreen forests during the past 100 years, but this was overridden by LULCC. However, there is no evidence from field measurements to support or disprove this claim. While there are studies on the consequences of LULCC on C pools at the site and regional levels (Hughes et al., 1999; Jaramillo et al., 2003; de Jong et 
al., 2010), there is very little work on the effect of climate change on NBP over Mexico (e.g., Dai et al., 2014), making it a fundamental missing piece in our understanding of the $\mathrm{C}$ cycle at local to regional scales. This is particularly important because the DGVMs we used are poorly constrained for their drought response (Morales et al., 2007; Sitch et al., 2003), a key process for the $\mathrm{C}$ balance over the arid regions of Mexico (grasslands/shrublands), which cover about $40 \%$ of the land area.

\subsection{Future}

In three out of four scenarios, Mexico represents a potential $\mathrm{C}$ sink in the remaining of this century. It is only in the scenario with the highest temperature and lowest precipitation (RCP8.5) that the country actually turns into a $\mathrm{C}$ source. While the $\mathrm{CO}_{2}$ fertilization dominates the magnitude of the sink across all RCPs, the effect of climate becomes more negative and predominant as the RCP becomes more extreme (Table 6). Similar modeling results have been found at the global scale, with an increasing climate-carbon feedback as the future scenario becomes more extreme (Cox et al., 2000; Friedlingstein et al., 2006).

Important considerations should be taken into account. The $\mathrm{CO}_{2}$ fertilization effect is likely counterbalanced not only by climate but also by the effect of limiting nutrients on $\mathrm{C}$ uptake - a process not considered in many Earth system models (ESMs; Reich et al., 2006; 2014, Zaehle et al., 2015) or by more severe fires as a result of more intense and recurrent ENSO (El Niño-Southern Oscillation; Yocom et al., 2010). Additionally, as shown by the past trends, a decrease in the MRT of soil $\mathrm{C}$ can change an ecosystem from a $\mathrm{C}$ sink into a $\mathrm{C}$ source. There is a lack of field information to estimate MRT and its response to temperature and soil moisture to fully understand the implications for the future of stored $\mathrm{C}$, especially in tropical and sub-tropical ecosystems.

\subsection{Limitations and considerations}

Although all our calculations are based on state-of-the-art data sets and models, several limitations must be taken into account. First, our study only comprises data that were either freely available (or will be soon) or published. Several government agencies in Mexico (e.g., CONABIO, CONAFOR and INEGI) have concentrated on producing new, more comprehensive and updated data sets than those used in this study. This means that our results should be revised in light of newer data, in particular with the inclusion of additional time slices in the field data, which can facilitate the comparison of modeled and observed changes in the $\mathrm{C}$ stocks.

Second, most of the data sets we used are improved constantly (e.g., models that include additional processes and flux tower data are steadily increasing); therefore, our evaluation of the $\mathrm{C}$ cycle in Mexico should improve as these products evolve. Also, and particularly important, models will in- clude additional processes such as fire (although some of the models used already included a fire module), nutrient limitations, a more complex representation of agriculture and finer-scale processes (such as landslides or floods), to mention a few.

Finally, while we tried to tackle the large heterogeneity of the country, it is quite clear that the spatial resolution used cannot provide a detailed analysis. Thus, our results should be used with caution when comparing them with site-level data and are better fit for country-level comparisons. In this sense, additional local/regional modeling studies with appropriate forcing data are a fundamental missing link to compare the different approaches to evaluate the $\mathrm{C}$ cycle over complex and dynamic terrains.

\section{Final remarks}

We quantify different aspects of the $\mathrm{C}$ cycle for Mexico (GPP and the total land $\mathrm{C}$ flux, as well as vegetation and soil $\mathrm{C}$ stocks) using different products over three time periods. As far as we know, this is the first time these pools and fluxes have been quantified for the whole country with a processbased approach. It takes into account different drivers (e.g., $\mathrm{CO}_{2}$, climate and LULCC) and provides a more realistic estimate of the $\mathrm{C}$ cycle for the country. Additionally, we quantify fluxes (e.g., GPP and NBP), not previously estimated at the country scale.

Contrary to inventory-based estimates (de Jong et al., 2010; Pacala et al., 2007; Hayes et al., 2012), our analysis shows that over the last 100 years and recent decades the country has been a $\mathrm{C}$ sink. Our results suggest this has resulted mainly from the positive effect of $\mathrm{CO}_{2}$ fertilization and to precipitation and temperature changes in some regions. This pattern is likely to persist, although with a diminishing trend, over the remaining part of the century. Such a sink, however, only accounts for $11 \%$ of $\mathrm{C}$ emissions from fossil fuels during the period, which clearly points towards the need of more fuel-efficient policies and emissions controls.

Our work also identifies the need to study the role of drought in drylands (e.g., grasslands and shrublands) and to determine soil carbon MRT in tropical ecosystems. Finally, as we used data from global sources (e.g., DGVMs, ESMs, satellite), the methodology proposed here can be used to analyze the full $\mathrm{C}$ cycle of regions elsewhere.

\section{The Supplement related to this article is available online at doi:10.5194/bg-13-223-2016-supplement.}

Author contributions. G. Murray-Tortarolo, P. Friedlingstein, S. Sitch and V. J. Jaramillo designed, executed and wrote the paper. F. Murguía-Flores, A. Anav and Y. Liu provided and analyzed data. 
The rest of the authors provided the DGVMs data and provided critical comments on the manuscript.

Acknowledgements. The lead author (G. Murray-Tortarolo) thanks CONACYT-CECTI, the University of Exeter and Secretaría de Educación Pública (SEP) for their funding of this project. The authors extend their thanks to Carlos Ortiz Solorio and to the Colegio de Posgraduados for the field soil data and to the Alianza Redd + Mexico for the field biomass data. This project would not have been possible without the valuable data from the CMIP5 models. A. Arneth, G. Murray-Tortarolo, A. Wiltshire and S. Sitch acknowledge the support of the European Commission-funded project LULCC4C (grant no. 603542). A. Wiltshire was partsupported by the Joint UK DECC/Defra Met Office Hadley Centre Climate Programme (GA01101).

Edited by: T. Keenan

\section{References}

Alianza MREDD+: Mapa y base de datos sobre la distribución de la biomasa aérea de la vegetación leñosa en México, Woods Hole Research Center, USAID, CONAFOR, CONABIO, Proyecto México Noruega, México, 2013.

Anav, A., Friedlingstein, P., Kidston, M., Bopp, L., Ciais, P., Cox, P., Jones, C., Jung, M., Myneni, R., and Zhu, Z.: Evaluating the Land and Ocean Components of the Global Carbon Cycle in the CMIP5 Earth System Models, J. Clim., 26, 6801-6843, doi:10.1175/JCLI-D-12-00417.1, 2013.

Batjes, N. H.: Total carbon and nitrogen in the soils of the world, Eur. J. Soil Sci., 47, 151-163, doi:10.1111/j.13652389.1996.tb01386.x, 1996.

Búrquez, A., Martínez-Yrízar, A., Núñez, S., Quintero, T., and Aparicio, A.: Aboveground biomass in three Sonoran Desert communities: Variability within and among sites using replicated plot harvesting, J. Arid Environ., 74, 1240-1247, doi:10.1016/j.jaridenv.2010.04.004, 2010.

Cairns, M.A., Olmsted, I., Granados, J., and Argaez, J.: Composition and aboveground tree biomass of a dry semi-evergreen forest on Mexico's Yucatan Peninsula, For. Ecol. Manag., 186, 125132, doi:10.1016/S0378-1127(03)00229-9, 2003.

Carvalhais, N., Forkel, M., Khomik, M., Bellarby, J., Jung, M., Migliavacca, M., Mu, M., Saatchi, S., Santoro, M., Thurner, M., Weber, U., Ahrens, B., Beer, C., Cescatti, A., Randerson, J. T., and Reichstein, M.: Global covariation of carbon turnover times with climate in terrestrial ecosystems, Nature, 514, 213-217, doi:10.1038/nature13731, 2014.

Cayan, D. R., Das, T., Pierce, D. W., Barnett, T. P., Tyree, M., and Gershunov, A., Future dryness in the southwest US and the hydrology of the early 21 st century drought, P. Natl. Acad. Sci. USA, 107, 21271-21276, doi:10.1073/pnas.0912391107, 2010.

Challenger, A.: Utilización y conservación de los ecosistemas terrestres de México, Pasado, presente y futuro, Conabio, IBUNAM y Agrupación Sierra Madre, México, 1-847, 1998.

Ciais, P., Sabine, C., Bala, G., Bopp, L., Brovkin, V., Canadell, J., Chhabra, A., DeFries, R., Galloway, J., Heimann, M., Jones, C.,
Le Quéré, C., Myneni, R. B., Piao, S., and Thornton, P.: Carbon and Other Biogeochemical Cycles, in: Climate Change 2013: The Physical Science Basis. Contribution of Working Group I to the Fifth Assessment Report of the Intergovernmental Panel on Climate Change, edited by: Stocker, T. F., Qin, D., Plattner, G.-K., Tignor, M., Allen, S. K., Boschung, J., Nauels, A., Xia, Y., Bex, V., and Midgley, P. M., Cambridge University Press, Cambridge, United Kingdom and New York, NY, USA, 465570, 2013.

Cox, P. M., Betts, R. A., Jones, C. D., Spall, S. A., and Totterdell, I. J.: Acceleration of global warming due to carbon-cycle feedbacks in a coupled climate model, Nature 408, 184-187, doi:10.1038/35041539, 2000.

Cruz-Gaistardo, C. and Paz-Pellat, F.: Mapa de carbono orgánico de los suelos de la República Mexicana, in: Estado Actual del Conocimiento del Ciclo del Carbono y sus Interacciones en México: Síntesis a 2013, edited by: Paz-Pellat, F., Wong-González, J., Bazan, M., and Saynes, V., Programa Mexicano del Carbono. Texcoco, Estado de México, México, ISBN 978-607-96490-1-2, $702,2014$.

Dai, Z., Birdsey, R. A., Johnson, K. D., Dupuy, J. M., HernandezStefanoni, J. L., and Richardson, K.: Modeling carbon stocks in a secondary tropical dry forest in the Yucatan Peninsula, Mexico, Water. Air. Soil Pollut., 225, 1-15, doi:10.1007/s11270-0141925-x, 2014.

De Jong, B., Anaya, C., Masera, O., Olguín, M., Paz, F., Etchevers, J., Martínez, R.D., Guerrero, G., and Balbontín, C.: Greenhouse gas emissions between 1993 and 2002 from land-use change and forestry in Mexico, For. Ecol. Manag., 260, 1689-1701, doi:10.1016/j.foreco.2010.08.011, 2010.

Dolman, A. J., Shvidenko, A., Schepaschenko, D., Ciais, P., Tchebakova, N., Chen, T., van der Molen, M. K., Belelli Marchesini, L., Maximov, T. C., Maksyutov, S., and Schulze, E.-D.: An estimate of the terrestrial carbon budget of Russia using inventory-based, eddy covariance and inversion methods, Biogeosciences, 9, 5323-5340, doi:10.5194/bg-9-5323-2012, 2012.

Escobar, E., Maass, M., Alcocer, J., Azpra, E., Falcón, L. I., Gallegos, A., García, F. J., García-Oliva, F., Jaramillo, V., Lecuanda, R., Magaña, V., Martínez-Yrízar, A., Muhlia, A., Rodríguez, R., and Zavala-Hidalgo, J.: Diversidad de procesos funcionales en los ecosistemas, in: Capital natural de México, vol. I: Conocimiento actual de la biodiversidad, CONABIO, México, ISBN 978-607-7607-03-8, 2008, 620 pp., 2008.

Enting, I. G., Rayner, P. J., and Ciais, P.: Carbon Cycle Uncertainty in REgional Carbon Cycle Assessment and Processes (RECCAP), Biogeosciences, 9, 2889-2904, doi:10.5194/bg-9-28892012, 2012.

Espinosa, D.E., Ocegueda, S., Aguilar, C., Flores-Villela, O., and Llorente-Bousquets, J.,: El conocimiento biogeográfico de las especies y su regionalización natural, in: Capital natural de México, vol. I: Conocimiento actual de la biodiversidad, CONABIO, México, ISBN 978-607-7607-03-8, 620 pp., 2008.

Etchevers-Barra, J., Paz-Pellat, F, Saynes-Santillán, V., CarrascoFuentes, M., Cruz-Gaistardo, C. O., Hidalgo-Moreno, C. I., Padilla-Cuevas, J., and Barrales-Brito, E.: El carbono en los ecosistemas terrestres de México, pp. 689, in: Estado Actual del Conocimiento del Ciclo del Carbono y sus Interacciones en México: Síntesis a Programa Mexicano del Carbono, edited by: PazPellat, F., Wong-González, J., Bazan, M., and Saynes, V., Tex- 
coco, Estado de México, México, ISBN 978-607-96490-1-2, 702 pp., 2014.

FAO/IIASA/ISRIC/ISSCAS/JRC: Harmonized World Soil Database (version 1.2), 2012.

Farquhar, G. D. and Sharkey, T. D.: Stomatal Conductance and Photosynthesis, Annu. Rev. Plant Physiol., 33, 317-345, doi:10.1146/annurev.pp.33.060182.001533, 1982.

Friedlingstein, P., Cox, P., Betts, R., Bopp, L., von Bloh, W., Brovkin, V., Cadule, P., Doney, S., Eby, M., Fung, I., Bala, G., John, J., Jones, C., Joos, F., Kato, T., Kawamiya, M., Knorr, W., Lindsay, K., Matthews, H. D., Raddatz, T., Rayner, P., Reick, C., Roeckner, E., Schnitzler, K.-G., Schnur, R., Strassmann, K., Weaver, A. J., Yoshikawa, C., and Zeng, N.: Climate-Carbon Cycle Feedback Analysis: Results from the C4MIP Model Intercomparison, J. Clim. 19, 3337-3353, doi:10.1175/JCLI3800.1, 2006.

Friedlingstein, P., Meinshausen, M., Arora, V. K., Jones, C. D., Anav, A., Liddicoat, S. K., and Knutti, R.: Uncertainties in CMIP5 Climate Projections due to Carbon Cycle Feedbacks, J. Clim. 27, 511-526, doi:10.1175/JCLI-D-12-00579.1, 2013.

Friend, A. D., Lucht, W., Rademacher, T. T., Keribin, R., Betts, R., Cadule, P., Ciais, P., Clark, D.B., Dankers, R., Falloon, P.D., Ito, A., Kahana, R., Kleidon, A., Lomas, M. R., Nishina, K., Ostberg, S., Pavlick, R., Peylin, P., Schaphoff, S., Vuichard, N., Warszawski, L., Wiltshire, A., and Woodward, F. I., Carbon residence time dominates uncertainty in terrestrial vegetation responses to future climate and atmospheric $\mathrm{CO}_{2}$, P. Natl. Acad. Sci. USA, 111, 3280-3285, doi:10.1073/pnas.1222477110, 2014.

Garcia-Moya, E. and Montanes-Castro, P: Saline grassland near Mexico City, in: Primary Productivity of Grass Ecosystems of the Tropics and Sub-Tropics, Chapman and Hall, London, 7099, 1992.

Gloor, M., Gatti, L., Brienen, R., Feldpausch, T. R., Phillips, O. L., Miller, J., Ometto, J. P., Rocha, H., Baker, T., de Jong, B., Houghton, R. A., Malhi, Y., Aragão, L. E. O. C., Guyot, J.-L., Zhao, K., Jackson, R., Peylin, P., Sitch, S., Poulter, B., Lomas, M., Zaehle, S., Huntingford, C., Levy, P., and Lloyd, J.: The carbon balance of South America: a review of the status, decadal trends and main determinants, Biogeosciences, 9, 5407-5430, doi:10.5194/bg-9-5407-2012, 2012.

Grover, H. D. and Musick, H. B.: Shrubland encroachment in southern New Mexico, USA: An analysis of desertification processes in the American southwest, Clim. Change 17, 305-330, doi:10.1007/BF00138373, 1990.

Harris, I., Jones, P. D., Osborn, T. J., Lister, D. H.: Updated high-resolution grids of monthly climatic observations - the CRU TS3.10 Dataset, Int. J. Climatol, 34, 623-642, doi:10.1002/joc.3711. 2014.

Hayes, D. J., Turner, D. P., Stinson, G., McGuire, A. D., Wei, Y., West, T. O., Heath, L. S., de Jong, B., McConkey, B. G., Birdsey, R. A., Kurz, W. A., Jacobson, A. R., Huntzinger, D. N., Pan, Y., Post, W. M., and Cook, R. B.: Reconciling estimates of the contemporary North American carbon balance among terrestrial biosphere models, atmospheric inversions, and a new approach for estimating net ecosystem exchange from inventory-based data, Glob. Change Biol., 18, 1282-1299, doi:10.1111/j.13652486.2011.02627.x, 2012.

Hughes, R. F., Kauffman, J. B., and Jaramillo, V. J.: Biomass, carbon, and nutrient dynamics of secondary forests in a humid tropical region of méxico, Ecology 80, 1892-1907, doi:10.1890/0012-9658(1999)080[1892:BCANDO]2.0.CO;2, 1999.

Jasso, R.: Crecimiento, biomasa y carbono arbóreo en un gradiente altitudinal en bosques templados. Tesis de Maestría, Posgrado en Ciencias Biológicas, UNAM, 2014.

Jung, M., Reichstein, M., and Bondeau, A.: Towards global empirical upscaling of FLUXNET eddy covariance observations: validation of a model tree ensemble approach using a biosphere model, Biogeosciences, 6, 2001-2013, doi:10.5194/bg-6-20012009, 2009.

Jung, M., Reichstein, M., Margolis, H. A., Cescatti, A., Richardson, A. D., Arain, M. A., Arneth, A., Bernhofer, C., Bonal, D., Chen, J., Gianelle, D., Gobron, N., Kiely, G., Kutsch, W., Lasslop, G., Law, B. E., Lindroth, A., Merbold, L., Montagnani, L., Moors, E. J., Papale, D., Sottocornola, M., Vaccari, F., and Williams, C.: Global patterns of land-atmosphere fluxes of carbon dioxide, latent heat, and sensible heat derived from eddy covariance, satellite, and meteorological observations, J. Geophys. Res.-Biogeo., 116, G00J07, doi:10.1029/2010JG001566, 2011.

Keeling, C. D., Whorf, T. P., Wahlen, M., and Van Der Plicht, J.: Interannual extremes in the rate of rise of atmospheric carbon dioxide since 1980, Nature, 375, 666-670, 1995.

King, A. W., Hayes, D. J., Huntzinger, D. N., West, T. O., and Post, W. M.: North American carbon dioxide sources and sinks: magnitude, attribution, and uncertainty, Front. Ecol. Environ., 10, 512-519, doi:10.1890/120066, 2012.

King, A. W., Andres, R. J., Davis, K. J., Hafer, M., Hayes, D. J., Huntzinger, D. N., de Jong, B., Kurz, W. A., McGuire, A. D., Vargas, R., Wei, Y., West, T. O., and Woodall, C. W.: North America's net terrestrial $\mathrm{CO}_{2}$ exchange with the atmosphere 1990-2009, Biogeosciences, 12, 399-414, doi:10.5194/bg-12399-2015, 2015.

Le Quéré, C. L., Moriarty, R., Andrew, R. M., Peters, G. P., Ciais, P., Friedlingstein, P., Jones, S. D., Sitch, S., Tans, P., Arneth, A., Boden, T. A., Bopp, L., Bozec, Y., Canadell, J. G., Chevallier, F., Cosca, C. E., Harris, I., Hoppema, M., Houghton, R. A., House, J. I., Jain, A., Johannessen, T., Kato, E., Keeling, R. F., Kitidis, V., Klein Goldewijk, K., Koven, C., Landa, C. S., Landschützer, P., Lenton, A., Lima, I. D., Marland, G., Mathis, J. T., Metzl, N., Nojiri, Y., Olsen, A., Ono, T., Peters, W., Pfeil, B., Poulter, B., Raupach, M. R., Regnier, P., Rödenbeck, C., Saito, S., Salisbury, J. E., Schuster, U., Schwinger, J., Séférian, R., Segschneider, J., Steinhoff, T., Stocker, B. D., Sutton, A. J., Takahashi, T., Tilbrook, B., van der Werf, G. R., Viovy, N., Wang, Y.-P., Wanninkhof, R., Wiltshire, A., and Zeng, N.: Global carbon budget 2014, Earth Syst. Sci. Data Discuss., 7, 521-610, doi:10.5194/essdd-7-521-2014, 2014.

Liu, Y. Y., Parinussa, R. M., Dorigo, W. A., De Jeu, R. A. M., Wagner, W., van Dijk, A. I. J. M., McCabe, M. F., and Evans, J. P.: Developing an improved soil moisture dataset by blending passive and active microwave satellite-based retrievals, Hydrol. Earth Syst. Sci., 15, 425-436, doi:10.5194/hess-15-425-2011, 2011.

Liu, Y. Y., Evans, J. P., McCabe, M. F., de Jeu, R. A. M., van Dijk, A. I. J. M., Dolman, A. J., and Saizen, I.: Changing climate and overgrazing are decimating Mongolian steppes, PLoS ONE 8, e57599, doi10.1371/journal.pone.0057599, 2013.

Martínez-Yrízar, A., Maass, J. M., Pérez-Jiménez, L. A., and Sarukhán, J.: Net primary productivity of a tropical deciduous 
forest ecosystem in western Mexico, J. Trop. Ecol., 12, 169-175, doi:10.1017/S026646740000938X, 1996.

Masera, O. R., Cerón, A. D., and Ordóñez, A.: Forestry mitigation options for Mexico: Finding synergies between $\mathrm{Na}-$ tional sustainable development priorities and global concerns, Mitig. Adapt. Strateg, Glob. Change 6, 291-312, doi:10.1023/A:1013327019175, 2001.

Morales, P., Hickler, T., Rowell, D. P., Smith, B., and Sykes, M. T.: Changes in European ecosystem productivity and carbon balance driven by regional climate model output, Glob. Change Biol., 13, 108-122, doi:10.1111/j.1365-2486.2006.01289.x, 2007.

Murray-Tortarolo, G., et al.: Changes in the dry season intensity are a key driver of trends in NPP, submitted, 2015.

Navar, J., Rodriguez-Flores, F. de J., Domínguez-Calleros, P. A., and Pérez-Verdín, G.: Diversity-Productivity Relationship in the Northeastern Tamaulipan Thornscrub Forest of Mexico, Int. J. Ecol., 196073, e196073, doi:10.1155/2014/196073, 2014.

Norby, R. J., DeLucia, E. H., Gielen, B., Calfapietra, C., Giardina, C. P., King, J. S., Ledford, J., McCarthy, H. R., Moore, D. J. P., Ceulemans, R., De Angelis, P., Finzi, A. C., Karnosky, D. F., Kubiske, M. E., Lukac, M., Pregitzer, K. S., ScarasciaMugnozza, G. E., Schlesinger, W. H., and Oren, R.: Forest response to elevated $\mathrm{CO}_{2}$ is conserved across a broad range of productivity, P. Natl. Acad. Sci. SA, 102, 18052-18056, doi:10.1073/pnas.0509478102, 2005.

Pacala, S., Birdsey, R., Bridgham, S., Conant, R., Davis, K., Houghton, R., Jenkins, J., Johnston, M., Marland, G., and Paustian, K.: The North American Carbon Budget Past and Present, in: The First State of the Carbon Cycle Report (SOCCR): The North American Carbon Budget and Implications for the Global Carbon Cycle, A Report by the US Climate Change Science Program and the Subcommittee on Global Change Research, National Oceanic and Atmospheric Administration, National Climatic Data Center, Asheville, NC, USA, 29-36, 2007.

Piao, S. L., Ito, A., Li, S. G., Huang, Y., Ciais, P., Wang, X. H., Peng, S. S., Nan, H. J., Zhao, C., Ahlström, A., Andres, R. J., Chevallier, F., Fang, J. Y., Hartmann, J., Huntingford, C., Jeong, S., Levis, S., Levy, P. E., Li, J. S., Lomas, M. R., Mao, J. F., Mayorga, E., Mohammat, A., Muraoka, H., Peng, C. H., Peylin, P., Poulter, B., Shen, Z. H., Shi, X., Sitch, S., Tao, S., Tian, H. Q., Wu, X. P., Xu, M., Yu, G. R., Viovy, N., Zaehle, S., Zeng, N., and Zhu, B.: The carbon budget of terrestrial ecosystems in East Asia over the last two decades, Biogeosciences, 9, 3571-3586, doi:10.5194/bg-9-3571-2012, 2012.

Ramankutty, N. and Foley, J. A.: Estimating historical changes in global land cover: Croplands from 1700 to 1992, Glob. Biogeochem. Cy., 13, 997-1027, doi:10.1029/1999GB900046, 1999.

Reich, P. B., Hobbie, S. E., Lee, T., Ellsworth, D. S., West, J. B., Tilman, D., Knops, J. M. H., Naeem, S., and Trost, J.: Nitrogen limitation constrains sustainability of ecosystem response to $\mathrm{CO}_{2}$, Nature 440, 922-925, doi:10.1038/nature04486, 2006.

Reich, P. B., Hobbie, S. E., and Lee, T. D.: Plant growth enhancement by elevated $\mathrm{CO}_{2}$ eliminated by joint water and nitrogen limitation, Nat. Geosci., 7, 920-924, doi:10.1038/ngeo2284, 2014.
Reimer, J. J., Vargas, R., Rivas, D., Gaxiola-Castro, G., HernandezAyon, J. M., and Lara-Lara, R.: Sea Surface Temperature Influence on Terrestrial Gross Primary Production along the Southern California Current, PloS One, 10, e0125177, doi:10.1371/journal.pone.0125177, 2015.

Running, S. W., Nemani, R. R., Heinsch, F. A., Zhao, M., Reeves, M., and Hashimoto, H.: A Continuous SatelliteDerived Measure of Global Terrestrial Primary Production, BioScience, 54, 547-560, doi:10.1641/00063568(2004)054[0547:ACSMOG]2.0.CO;2, 2004.

Segura-Castruita, M. A., Sánchez-Guzmán, P., Ortiz-Solorio, C. A., and Gutiérrez-Castorena, M. del C.: Carbono orgánico de los suelos de México [WWW Document], Terra Latinoam, available at: http://www.redalyc.org/articulo.oa?id=57323103 (last access: 12 July 2015), 2005.

Sitch, S., Smith, B., Prentice, I. C., Arneth, A., Bondeau, A., Cramer, W., Kaplan, J. O., Levis, S., Lucht, W., Sykes, M.T., Thonicke, K., and Venevsky, S.: Evaluation of ecosystem dynamics, plant geography and terrestrial carbon cycling in the LPJ dynamic global vegetation model, Glob. Change Biol., 9, 161-185, doi:10.1046/j.1365-2486.2003.00569.x, 2003.

Sitch, S., Friedlingstein, P., Gruber, N., Jones, S. D., MurrayTortarolo, G., Ahlström, A., Doney, S. C., Graven, H., Heinze, C., Huntingford, C., Levis, S., Levy, P. E., Lomas, M., Poulter, B., Viovy, N., Zaehle, S., Zeng, N., Arneth, A., Bonan, G., Bopp, L., Canadell, J. G., Chevallier, F., Ciais, P., Ellis, R., Gloor, M., Peylin, P., Piao, S. L., Le Quéré, C., Smith, B., Zhu, Z., and Myneni, R.: Recent trends and drivers of regional sources and sinks of carbon dioxide, Biogeosciences, 12, 653679, doi:10.5194/bg-12-653-2015, 2015.

Taylor, K. E., Stouffer, R. J., and Meehl, G. A.: An Overview of CMIP5 and the Experiment Design, B. Am. Meteorol. Soc., 93, 485-498, doi:10.1175/BAMS-D-11-00094.1, 2011.

Valentini, R., Arneth, A., Bombelli, A., Castaldi, S., Cazzolla Gatti, R., Chevallier, F., Ciais, P., Grieco, E., Hartmann, J., Henry, M., Houghton, R. A., Jung, M., Kutsch, W. L., Malhi, Y., Mayorga, E., Merbold, L., Murray-Tortarolo, G., Papale, D., Peylin, P., Poulter, B., Raymond, P. A., Santini, M., Sitch, S., Vaglio Laurin, G., van der Werf, G. R., Williams, C. A., and Scholes, R. J.: A full greenhouse gases budget of Africa: synthesis, uncertainties, and vulnerabilities, Biogeosciences, 11, 381-407, doi:10.5194/bg11-381-2014, 2014.

Verduzco, V. S., Garatuza-Payán, J., Yépez, E. A., Watts, C. J., Rodríguez, J. C., Robles-Morua, A., and Vivoni, E. R.: Variations of net ecosystem production due to seasonal precipitation differences in a tropical dry forest of northwest Mexico. J. Geophys. Res.-Biogeosci., 120, JG003119, doi:10.1002/2015JG003119, 2015.

Yocom, L. L., Fulé, P. Z., Brown, P. M., Cerano, J., VillanuevaDíaz, J., Falk, D. A., and Cornejo-Oviedo, E.: El Niño-Southern Oscillation effect on a fire regime in northeastern Mexico has changed over time, Ecology, 91, 1660-1671, doi:10.1890/090845.1, 2010. 